\title{
Distribution of arsenic, silver, cadmium, lead and other trace elements in water, sediment and macrophytes in the Kenyan part of Lake Victoria: spatial, temporal and bioindicative aspects
}

\author{
James Omondi Outa ${ }^{1,2,3} \cdot$ Chrispin O. Kowenje $^{3} \cdot$ Christof PlessI $^{2} \cdot$ Franz Jirsa $^{2,4}$ (D) \\ Received: 5 June 2019 / Accepted: 12 September 2019 /Published online: 20 November 2019 \\ (C) The Author(s) 2019
}

\begin{abstract}
This is the first detailed report on the distribution of $\mathrm{Ni}, \mathrm{As}, \mathrm{Sr}$ and $\mathrm{Ag}$ in water, sediments and macrophytes from Lake Victoria, complemented with recent data on the heavy metals $\mathrm{Cr}, \mathrm{Cu}, \mathrm{Zn}, \mathrm{Cd}$ and $\mathrm{Pb}$. The study was conducted over an 11-month period at five sites in the Kenyan part of Lake Victoria: four sites in the Winam Gulf influenced by various anthropogenic pressures including a site near Kisumu City, and one in the main lake, perceived to have lesser direct anthropogenic influence. Compared with the main lake site, the water in Winam Gulf had significantly higher values for electrical conductivity and concentrations of dissolved components: organic carbon and bound nitrogen, as well as major and most trace elements. This contamination is also evident in surface sediments, which contained significantly higher levels of $\mathrm{Cr}, \mathrm{Zn}, \mathrm{As}, \mathrm{Ag}, \mathrm{Cd}$ and $\mathrm{Pb}$ compared with the main lake site. The mean levels of $\mathrm{Cr}, \mathrm{Cu}, \mathrm{Zn}, \mathrm{Ag}$ and $\mathrm{Pb}$ exceeded probable effect levels at least at one of the gulf sites. The sediments at the Kisumu City site were classified as severely polluted with $\mathrm{Cu}$ (up to $259 \mathrm{mg} / \mathrm{kg} \mathrm{dw}$ ) and $\mathrm{Pb}$ (up to $1188 \mathrm{mg} / \mathrm{kg} \mathrm{dw}$ ). The sediment cores showed significantly higher levels of $\mathrm{Cu}, \mathrm{Zn}, \mathrm{Ag}, \mathrm{Cd}$ and $\mathrm{Pb}$ in the surface $(0-3 \mathrm{~cm})$ versus subsurface $(22-25$ $\mathrm{cm}$ ) layer at the Kisumu City site, indicating increasing pollution by these elements within the last 15 years. This is also the first report on trace elements in the emergent water plant Vossia cuspidata and submerged plant Ceratophyllum demersum from this lake. Even though the accumulation of most elements is comparable between C. demersum (whole plant) and V. cuspidata roots, the latter shows a better bioindicative potential. Contamination of the gulf with $\mathrm{Ni}, \mathrm{Cu}, \mathrm{Zn}, \mathrm{Ag}, \mathrm{Cd}$ and $\mathrm{Pb}$ is well mirrored in $V$. cuspidata roots. V. cuspidata strongly restricts the acropetal transport of trace elements, and hence using the shoots as fodder does not pose a risk to livestock.
\end{abstract}

Keywords Heavy metals $\cdot$ Winam Gulf $\cdot$ Pollution $\cdot$ Ceratophyllum demersum $\cdot$ Vossia cuspidata

Responsible editor: Philippe Garrigues

Electronic supplementary material The online version of this article (https://doi.org/10.1007/s11356-019-06525-9) contains supplementary material, which is available to authorized users.

Franz Jirsa

franz.jirsa@univie.ac.at

1 Department of Limnology and Bio-Oceanography, University of Vienna, Althanstrasse 14, 1090 Vienna, Austria

2 Institute of Inorganic Chemistry, University of Vienna, Althanstrasse 14, 1090 Vienna, Austria

3 Department of Chemistry, Maseno University, P.O. Box 333, Maseno 40105, Kenya

4 Department of Zoology, University of Johannesburg, P.O. Box 524, Auckland Park 2006, South Africa

\section{Introduction}

Inland waterbodies are subject to pollution pressure worldwide (Akwiri et al. 2016). The pollutants may be of organic or inorganic nature and have a multitude of origins (Burton 2002). One major group of pollutants is trace elements including heavy metals and metalloids, which pose a threat to wildlife and humans at elevated concentrations (Miller et al. 2004). Although their natural occurrence in waterbodies is highly dependent on the geological background of the catchment area, anthropogenic activities have multiplied the concentrations of some of these elements during the last decades, in particular lead, mercury and copper (Lau et al. 1998; Aras et al. 2012). According to the Blacksmith Institute and Green Cross report by McCartor and Becker (2010), four out of the six top contaminants in the world are heavy metals $(\mathrm{Cr}, \mathrm{Hg}$ and $\mathrm{Pb})$ and the 
metalloid (As), from which an estimated 50 million people globally are at risk of toxic pollution at levels above international health standards.

Trace elements show different partitioning in the various compartments of waterbodies according to the physicochemical properties of the trace elements as well as the properties of the respective compartment (Zhang et al. 2014). The water phase, with its dissolved components, and the sediment are interconnected by biological and chemical processes. Investigating dissolved elements allows only a snapshot at the time of sampling because only a small portion of free metal ions remain dissolved in water (Hou et al. 2013). The other compartments (sediment and biota), however, can act as reservoirs for contaminants through bioaccumulation and trophic transfer (Burton 2002), enabling a more comprehensive assessment (Alonso et al. 2013). Sediments can also act as a source of trace elements in the water column (Galal and Shehata 2015). The elements in sediment are present in bound and ionexchangeable forms and can adversely affect sedimentdwelling organisms through direct toxicity (Hou et al. 2013). This calls for regularly monitoring the levels of trace elements in sediments. Although aquatic plants are common and easy to identify compared with other biota, the data on their accumulation of trace elements are rather scarce (Remon et al. 2013). Plants accumulate essential metals such as $\mathrm{Mg}, \mathrm{Fe}, \mathrm{Mn}, \mathrm{Zn}, \mathrm{Cu}$, $\mathrm{Mo}$ and $\mathrm{Ni}$, and some plants also accumulate elements that have no essential biological function (Brankovic et al. 2015). The mineral nutrition of sessile plants depends closely on the immediate growth medium characteristics, making them suitable bioindicators (Remon et al. 2013).

Inland waters and freshwater biodiversity constitute a valuable natural resource in economic, cultural, aesthetic, scientific and educational terms (Dudgeon et al. 2006). Lake Victoria, the largest lake in Africa, is the most important freshwater resource for the local population (Crul 1995), serving more than 30 million people (Awange and Obera 2007). Like many surface waters, it suffers from anthropogenic pressures. Muli (2006) noted that industrial, agricultural and domestic waste discharges have increased the levels of trace elements in the lake. Njuru and Hecky (2005) reported notable inshoreoffshore pollution gradients in several large embayments such as Winam Gulf, Murchison Bay and Mwanza Gulf, which are potential recipients of municipal and industrial wastes from rivers and the adjacent cities. Winam Gulf, also called Nyanza or Kavirondo Gulf, is semi-isolated from the main lake, receives input from the larger rivers (about 10\% of the total inflow into the lake) and faces high urban pollution from Kisumu City (Njuru et al. 2013). This gulf is therefore of great interest with regard to pollution studies.

Various studies have investigated the heavy metal levels in Lake Victoria. Onyari and Wandiga (1989), Mwamburi and Oloo (1996) and Kishe-Machumu and Machiwa (2003) focused on the distribution of selected trace elements $(\mathrm{Cr}, \mathrm{Mn}$,
$\mathrm{Fe}, \mathrm{Cu}, \mathrm{Zn}, \mathrm{Cd}, \mathrm{Hg}$ and $\mathrm{Pb})$ in surface sediments $(<5 \mathrm{~cm})$. Nonetheless, the information on the distribution and bioaccumulation of other trace elements such as $\mathrm{Ni}, \mathrm{As}, \mathrm{Sr}$ and $\mathrm{Ag}$ remains very scarce, with only one published study (Ochieng et al. 2006) on Ni and $\mathrm{Ag}$ in surface sediments. $\mathrm{Ag}$, for instance, is fast becoming an element of interest in aquatic pollution studies due to its toxicity and increased usage in various consumer products (Plessl et al. 2018; Yuan et al. 2018). Moreover, the distribution of trace elements in sediment cores has received very little attention in Lake Victoria. Ramlal et al.'s (2003) study on sediment cores in the Ugandan part of Lake Victoria focused solely on $\mathrm{Hg}$. The vertical distribution of elements in sediments is important because it reveals the history of pollution, especially in connection with terrestrial anthropogenic pressures (Skwierawski and Sidoruk 2014). Although aquatic plants are abundant in Lake Victoria, comprehensive data on their trace element contents are scarce. Mahommed and Makundi (2002) reported on metals (Mn, Fe, Co, Ni, Zn and $\mathrm{Pb}$ ) in the water hyacinth Eichhornia crassipes (Mart.) Solms in parts of Mwanza Gulf (Tanzania), where plants subject to industrial and domestic wastewater discharges had higher levels of trace elements than those in non-polluted areas. In assessing the contamination of wetland soils and plants around Lake Victoria (Uganda), Nabulo et al. (2008) found that the Benghal dayflower Commelina benghalensis L. and E. crassipes accumulate $\mathrm{Ni}, \mathrm{Cu}, \mathrm{Zn}, \mathrm{Cd}$ and $\mathrm{Pb}$ in their tissues. No information is available on the bioindicative aspects of the submerged non-rooted macrophyte hornwort Ceratophyllum demersum $\mathrm{L}$. and the abundant shoreline emergent macrophyte hippo grass Vossia cuspidata (Roxb.) Griff in Lake Victoria. Studies from Europe (Stanković et al. 2000) and China (Xing et al. 2013) show that $C$. demersum is a good indicator of freshwater pollution by trace elements, while Galal et al. (2017) noted that $V$. cuspidata has a good bioaccumulation ability for $\mathrm{Cr}, \mathrm{Mn}, \mathrm{Co}, \mathrm{Ni}, \mathrm{Cu}, \mathrm{Zn}, \mathrm{Cd}$ and $\mathrm{Pb}$ in Ismailia Canal, Egypt. We found no other studies on the bioaccumulation of As, $\mathrm{Sr}$ and $\mathrm{Ag}$ in V. cuspidata; this study therefore gives the first insights. Like most grasses, V. cuspidata is widely used as fodder for livestock by most communities around Lake Victoria (Sayer et al. 2018). This calls for investigating the potential risk associated with its utilization as animal feed.

This study investigates the general physico-chemical parameters, major and trace elements in water, sediments and two macrophyte species from the Kenyan part of the lake over a period of 11 months from five different sampling areas. The results help to demonstrate the spatial variations in chemical composition as well as potential temporal changes in the water phase and the sediments. The analyses of sediment cores from those five different sites provide a first insight into the history of trace element deposition. The trace elements in the two macrophytes are a first step in determining their bioindicative abilities and the possible risk posed by using $V$. cuspidata as fodder. 


\section{Materials and methods}

\section{Study area descriptions}

Lake Victoria, shared by Kenya, Tanzania and Uganda, is the world's largest tropical lake and the second largest freshwater lake in the world, covering a total of $69,000 \mathrm{~km}^{2}$ with a mean depth of $40 \mathrm{~m}$ and maximum depth of $79 \mathrm{~m}$ (Okungu et al. 2005). It is located along the equator between $0.5^{\circ} \mathrm{N}$ and $2.5^{\circ}$ $\mathrm{S}$ and $32^{\circ} \mathrm{E}$ and $34^{\circ} \mathrm{E}$ at an elevation of $1134 \mathrm{~m}$ above sea level, with a large catchment of $195,000 \mathrm{~km}^{2}$. The main river inlet (Kagera) drains through Rwanda, Burundi, Tanzania and Uganda, while the main river outlet is the Nile (Odada et al. 2004). The Kenyan portion of Lake Victoria lies just south of the equator between $0^{\circ} 6^{\prime} \mathrm{S}$ to $0^{\circ} 32^{\prime} \mathrm{S}$ and $34^{\circ} 13^{\prime} \mathrm{E}$ to $34^{\circ} 52^{\prime}$ $\mathrm{E}$; although its share is only $6 \%$ of the lake, it covers an area of about $4200 \mathrm{~km}^{2}$, of which $1400 \mathrm{~km}^{2}$ comprises the Winam Gulf (Lung'ayia et al. 2001). The Winam Gulf of Kenya (Fig. 1) is a shallow basin with an inshore (mean $4 \mathrm{~m}$, maximum 6 m depth) and offshore zone (mean $12 \mathrm{~m}$, maximum $43 \mathrm{~m}$ depth) (Crul 1995). The gulf receives high river inflows from western Kenya highlands (Njuru and Hecky 2005).

The equatorial climate at Lake Victoria basin is characterized by temperatures ranging between 20 and $35^{\circ} \mathrm{C}$ and a mean annual rainfall between 1000 and $1500 \mathrm{~mm}$ (Okungu et al. 2005). A number of records (Crul 1995; Okungu et al. 2005; Yang et al. 2015) show that there are two main rainy seasons in the Lake Victoria basin: the long rains during
March, April and May, resulting from the northward progression of the intertropical convergence zone (ITCZ), and the short rains in October and November, as the ITCZ moves southwards. The short rains can be intermittent or even fail in certain years (Crul 1995).

The five selected sites in the Kenyan part of Lake Victoria, both in the Winam Gulf and part of the main lake, are indicated in Fig. 1. The sampling sitesAsembo Bay (AB), Kisumu City (KM), Kisumu City outskirt (KK), Mainuga (MN) and Rusinga Island (RS) were selected based on the perceived different types and levels of anthropogenic pressures. Also taken into consideration were the water currents, which influence the movement of contaminants in the gulf. Njuru et al. (2013) reported that contaminants entering the gulf through river inflows and municipal sources are largely retained, with minimal exchange into the main lake. The Rusinga Island sampling point (RS) is part of the main lake, buffered by the large water body, and was therefore regarded to represent the general characteristics of the main lake. As noted by Awange and Obera (2007) and Kundu et al. (2017), the KM site presents a part of the lake that suffers from the industrial and municipal wastewater discharges associated with urbanization. The Kisat River flows into the lake at Kisumu City, whereas the Kibos River feeds the lake at the outskirts of the city (Fig. 1). The site at the outskirts of Kisumu City (KK) is situated near the Kibos River inlet and is buffered by a

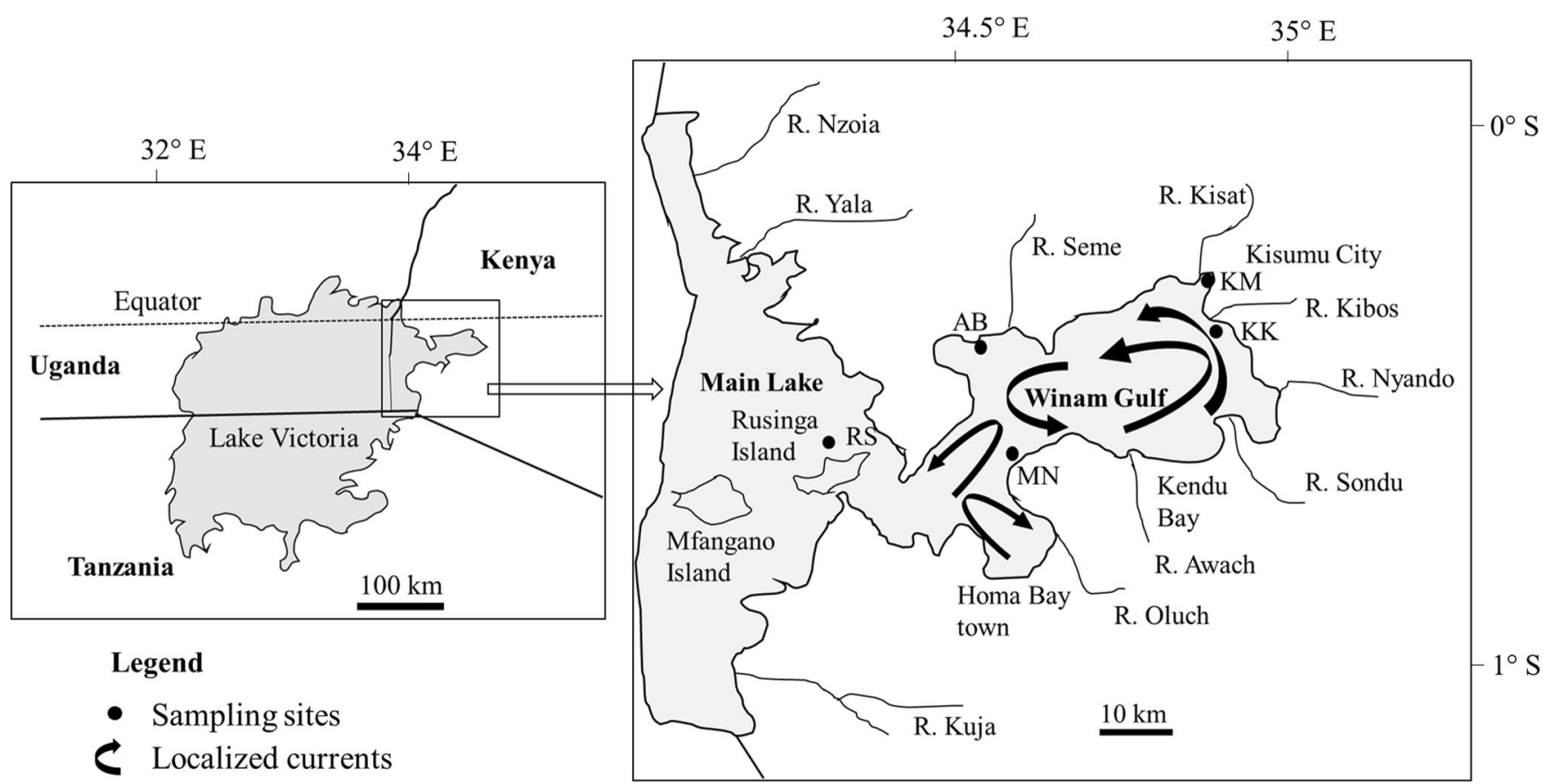

Fig. 1 Map of Lake Victoria indicating the study area and sampling sites. Modified from Njuru et al. (2013); black arrows indicate localized currents based on Okely et al. (2010). AB, Asembo Bay ( $0^{\circ} 11^{\prime} 10.2^{\prime \prime} \mathrm{S} 34^{\circ}$ $\left.23^{\prime} 35.8^{\prime \prime} \mathrm{E}\right)$; KM, Kisumu City ( $\left.0^{\circ} 05^{\prime} 16.4^{\prime \prime} \mathrm{S} 34^{\circ} 44^{\prime} 59.0^{\prime \prime} \mathrm{E}\right)$; KK,
Kisumu City outskirt ( $\left.0^{\circ} 09^{\prime} 41.4^{\prime \prime} \mathrm{S} 34^{\circ} 44^{\prime} 51.6^{\prime \prime} \mathrm{E}\right)$; MN, Mainuga $\left(0^{\circ}\right.$ $\left.20^{\prime} 48.7^{\prime \prime} \mathrm{S} 34^{\circ} 29^{\prime} 09.1^{\prime \prime} \mathrm{E}\right)$; and RS, Rusinga Island ( $0^{\circ} 23^{\prime} 20.5^{\prime \prime} \mathrm{S} 34^{\circ}$ $\left.11^{\prime} 48.9^{\prime \prime} \mathrm{E}\right)$ 
large wetland area dominated by papyrus Cyperus papyrus $\mathrm{L}$. The $\mathrm{AB}$ site, located on the northern shoreline, and the MN site to the south, are relatively rural sites within the mid-region of Winam Gulf. Rural farmlands in this region are potential sources of fertilizer runoff and sediment transport into the lake (Lung'ayia et al. 2001). Okely et al. (2010) showed limited horizontal mixing of water in these regions of Winam Gulf (AB, $\mathrm{KM}, \mathrm{KK}$ and $\mathrm{MN}$ ) (Fig. 1). The five sampling sites were therefore regarded to be potentially dissimilar in their physicochemical characteristics.

\section{Sampling and sample preparation}

Sampling in the lake took place over 11 months from September 2016 to July 2017. Temperature, pH and electrical conductivity (EC) were measured monthly at approximately $10 \mathrm{~cm}$ below the water surface using portable VOLTCRAFT® meters (model PHT-02 ATC and LWT-02 ATC, Lindenweg, Germany). Water samples were taken at the same points and were filtered through $0.2-\mu \mathrm{m}$ Acrodisc ${ }^{\circledR}$ PSF filters (PP membrane with a multilayer glassfibre pre-filter, PALL, Ann Arbor, USA) rinsed with $10 \mathrm{~mL}$ of distilled water prior to use, into $15-\mathrm{ml}$ acidrinsed polypropylene (PP) falcon tubes. They were then acidified to $\mathrm{pH} \approx 2$ with ultrapure acid (TraceSELECT® by Fluka, Steinheim, Germany). One filtered sample was acidified with $\mathrm{HNO}_{3}$ for analysis of major and trace elements and another one with $\mathrm{HCl}$ to determine dissolved nitrogen (DN) and dissolved organic carbon (DOC).

Surface sediments were taken monthly by scooping a $50-\mathrm{mL}$ PP tube into the sediment or with a plastic corer ( $5 \mathrm{~cm}$ diameter). At each site, samples were taken in triplicate approximately $50 \mathrm{~m}$ apart. They were transported under cooled conditions and protected from light to Maseno University laboratory in Kisumu City and frozen at $-21{ }^{\circ} \mathrm{C}$ until further processing. Sediment core samples were taken at least twice at each of the sampling sites. Samples were transported within the corer to the laboratory and stored at $21^{\circ} \mathrm{C}$ until further processing. After thawing them for a short time under warm water, the cores were slipped out of the corer and sliced into layers of about $3 \mathrm{~cm}$ using a ceramic knife at three separate depths (' $0 \mathrm{~cm}$ ', ' $15 \mathrm{~cm}$ ', ' $25 \mathrm{~cm}$ ') and transferred into 50-mL PP falcon tubes. For further preparation, all sediment samples were oven dried at $90{ }^{\circ} \mathrm{C}$ until weight constancy was reached (2-3 days). Dried sediment samples were homogenized in a porcelain mortar and pestle, sieved through a 1-mm stainless-steel sieve and filled into $15-\mathrm{mL}$ tubes for further storage.

Plants were handpicked wearing nitrile gloves, placed into 2-L plastic containers and covered with lake water for transport. During the study period, V. cuspidata samples were taken twice (October 2016 and May 2017) from the five sampling sites. C. demersum was found only at $\mathrm{AB}$ and RS in October 2016. Thereafter (from December 2016 to May 2017), $C$. demersum was not observed, coinciding with a period when most of inshore areas of the gulf were covered by E. crassipes. In the laboratory, samples were rinsed in Milli-Q ${ }^{\circledR}$ water. For C. demersum, a portion of the whole plant (approximately $5 \mathrm{~g}$ wet weight) was transferred into $50-\mathrm{mL}$ tubes. For $V$. cuspidata, portions of stems and roots (approximately $5 \mathrm{~g}$ each) were separately put into 50-mL tubes. All plant samples were oven dried for $48 \mathrm{~h}$ to constant weight at $90{ }^{\circ} \mathrm{C}$. The samples were shipped to the University of Vienna, Institute of Inorganic Chemistry laboratory, for further processing and chemical analysis.

Approximately $0.5 \mathrm{~g}$ of oven-dried, sieved sediment samples were weighed using an analytical balance into glass tubes, and $9 \mathrm{~mL}$ of $34 \% \mathrm{HNO}_{3}$ (TraceSELECT® Fluka) and $1 \mathrm{~mL}$ of $30 \% \mathrm{H}_{2} \mathrm{O}_{2}$ were added. Covered with air coolers, samples were processed for $2 \mathrm{~h}$ at $130{ }^{\circ} \mathrm{C}$ in a heating block. The leached samples were transferred to 20-mL volumetric flasks and topped up to volume using Milli-Q® water. Before analyses, samples were filtered through 0.2- $\mu \mathrm{m}$ PTFE membrane syringe filters (VWR, Radnor, USA). Reference samples comprising $0.2 \mathrm{~g}$ (dry weight) of marine sediment PACS-2 obtained from the National Research Council Canada (NRCC, Ottawa, Canada) were digested and diluted in the same manner as described above. A separate set of $0.5 \mathrm{~g}$ of the sediment samples was weighed into porcelain crucibles and ashed in a muffle furnace at $550{ }^{\circ} \mathrm{C}$ for $2 \mathrm{~h}$ to determine organic matter $(\mathrm{OM})$ as percent ash free dry weight (AFDW) by loss of ignition (Wetzel and Likens 1991).

Plant tissue samples were homogenized with a mortar and pestle, and approximately $0.2 \mathrm{~g}$ was digested in $9 \mathrm{~mL} 34 \%$ $\mathrm{HNO}_{3}$ (TraceSELECT® Fluka) and $1 \mathrm{~mL}$ of $30 \% \mathrm{H}_{2} \mathrm{O}_{2}$ using a microwave MARS XPRESS system (CEM Corporation, Smith Farm Rd, USA). The digested plant samples were transferred into 15-mL volumetric flasks and brought up to volume using Milli-Q ${ }^{\circledR}$ water. The leachates were filtered through 0.2- $\mu \mathrm{m}$ PTFE pre-syringe filters (VWR).

\section{Sample analyses}

Water analyses for $\mathrm{Na}, \mathrm{Mg}, \mathrm{K}, \mathrm{Ca}, \mathrm{Cr}, \mathrm{Mn}, \mathrm{Fe}, \mathrm{Ni}, \mathrm{Cu}, \mathrm{Zn}, \mathrm{As}$, $\mathrm{Sr}, \mathrm{Ag}, \mathrm{Cd}$ and $\mathrm{Pb}$ concentrations were carried out using total $\mathrm{X}$-ray reflection fluorescence spectrometry (S2 PicoFox TXRF, Bruker; Billerica, USA), flame atomic absorption spectrometry (flame-AAS; Analyst 200 by PerkinElmer, Waltham, USA) or graphite furnace atomic absorptions spectrometry (GF-AAS) using a PinAAcle 900Z (Pelkin Elmer), depending on the concentrations of the elements and the LODs of the instrument used. DOC and DN were measured in the filtered acidified water samples using a TOC-VCPH total organic carbon analyser by Shimadzu, Kyoto, Japan. 
Trace element (Cr, Ni, Cu, Zn, As, Sr, Ag, Cd and $\mathrm{Pb}$ ) concentrations in sediment and plant tissue were determined using total x-ray reflection fluorescence spectrometry (S2 PicoFox TXRF, Bruker) and, when necessary, graphite furnace atomic absorption spectrometry (GF-AAS) using a PinAAcle $900 \mathrm{Z}$ (Pelkin Elmer). Recovery rates from the analyses of reference samples as well as limits of detection (LODs) for sediment and plant samples are given in SM Table 1 and 2.

\section{Statistical analysis}

Statistical analysis was done using IBM SPSS version 21 . The Shapiro-Wilk test, which is very sensitive in detecting deviations from normality (Mohd and Yap 2011), was used to check for the normality of data distribution. The differences in spatial distribution of major and trace elements in water and sediment were determined by comparing sitespecific means. Parametric one-way ANOVA was applied for comparison of means where appropriate. For the post hoc test, Tukey's HSD was applied for pairwise mean comparisons where homogeneity of variance was established, whereas the Games Howell test was applied for unequal sample sizes and variances (Games and Howell 1976; Kim 2015). The non-parametric Kruskal-Wallis and MannWhitney $U$ tests (for pairwise comparisons) were applied for data sets without normal distribution. All differences were tested for significance at $P<0.05$.

The bioconcentration factors (BCFs) were determined according to the formula:

$B C F_{\left(\frac{x}{y}\right)}=\frac{\text { Concentration of element in } x}{\text { Concentration of element in } y}$

in which the variables $x$ and $y$ stand for matrices that are compared with each other, such as water, sediment and macrophyte tissue.

\section{Evaluation of sediment quality}

To evaluate the sediment quality, parameters that provide a reliable basis for classifying sediment as toxic or nontoxic were used following MacDonald et al. (2000), de Deckere et al. (2011) and Simpson et al. (2013). These parameters were threshold effect concentrations (TEC), the consensus-based levels below which toxic effects are rarely observed in sediment-dwelling organisms; consensus-based probable effect level (PEL), the concentrations above which toxic effects are generally observed; and severe effect level (SEL) at which sediments are considered heavily polluted and adverse effects occur in most benthic organisms. The trace element contents of all sediment samples, including the mean values for each sampling site, were compared with the respective metal guidelines.

\section{Results and discussion}

\section{Water-dissolved components}

The results for the physicochemical parameters, dissolved major and trace elements, as well as dissolved organic carbon (DOC) and dissolved bound nitrogen (DN) are presented in Table 1. The dissolved components were highest in Kisumu City (KM) and comparatively low at Rusinga Island (RS). Manganese was below the limit of detection (LOD) of 0.05 $\mathrm{mg} / \mathrm{L}$ in nearly all the samples except for the KM site, where 1.36 to $2.18 \mathrm{mg} / \mathrm{L}$ was recorded between February and May. $\mathrm{Ag}$ and $\mathrm{Cd}$ were below detection limits in all samples (LOD 0.1 and $0.07 \mu \mathrm{g} / \mathrm{L}$, respectively). Temporal trends (Fig. 2) indicate high levels of dissolved elements between March and May, especially at KM where for instance $\mathrm{K}$ increased from $11 \mathrm{mg} / \mathrm{L}$ in February to $78 \mathrm{mg} / \mathrm{L}$ in April; these results were mirrored in the electrical conductivity (EC) values. In the other four sampling sites, temporal variation was not prominent, which is reflected in the smaller standard deviations of the mean values at those sites (Table 1).

The comparatively high mean values of dissolved components at KM, which showed temporal variation, can be attributed to anthropogenic influences of the city. The KM site is located at an inshore part of Winam Gulf and is polluted by partially treated municipal and industrial discharges. Other sources of pollution include the washing of motor vehicles along the lakeshores and urban runoff from busy traffic and open garages, from where oil spills and particles of scrapped paint are washed into the lake. Moreover, several open domestic waste dump sites of Kisumu City are situated along the lake's shore (Awange and Obera (2007), Kundu et al. (2017)). The role played by the Kisat River in polluting the lake at this site is equally important. In assessing the ecological integrity of the Kisat River, Kobingi et al. (2009) noted that the river drains through farmlands in its middle reach and becomes heavily contaminated by industrial discharge and poorly treated sewage from Kisumu City at the lower reach. In contrast, the RS site, which is buffered by the main water body of the lake, displays significantly lower mean values of EC and dissolved components (DN, $\mathrm{Na}, \mathrm{Mg}, \mathrm{Ca}, \mathrm{Sr}$ ), with significantly lower variations compared with the other sites. This agrees with the findings of Ochieng et al. (2006), who noted that seasonal variability is not significant in large lakes like Lake Victoria. At the KM site, the elevated levels of EC, major and trace elements in surface water coincided with the long rain season (March-May). This indicates that storm water surface runoff through the city, and the Kisat River, played a major role in the physico-chemical characteristics of water here. Although KK is located just at the outskirts of Kisumu City, and near the discharge point of the Kibos River, most of the water quality parameters were very distinct from $\mathrm{KM}$ but comparable with those of the main lake site (RS). This can be 
Table 1 Physicochemical parameters and dissolved major and trace elements (mean \pm SD) of water in the study sites. Italic text: site with the highest mean concentrations for each parameter. Mean values of each parameter followed by same superscript letters do not differ significantly $(P>0.05)$

\begin{tabular}{|c|c|c|c|c|c|c|}
\hline Parameter & $\mathrm{AB}(n=10)$ & $\mathrm{KM}(n=11)$ & $\mathrm{KK}(n=9)$ & $\mathrm{MN}(n=8)$ & $\operatorname{RS}(n=11)$ & EU/OECD guidelines \\
\hline $\mathrm{T}\left({ }^{\circ} \mathrm{C}\right)$ & $27.7^{\mathrm{a}} \pm 1.6$ & $26.8^{\mathrm{a}} \pm 1.8$ & $28.1^{\mathrm{a}} \pm 2.8$ & $26.9^{\mathrm{a}} \pm 1.1$ & $27.3^{\mathrm{a}} \pm 1.2$ & \\
\hline $\mathrm{pH}$ & $7.4^{\mathrm{a}} \pm 0.4$ & $7.7^{\mathrm{ab}} \pm 1.2$ & $6.9^{\mathrm{a}} \pm 0.5$ & $7.9^{b} \pm 0.4$ & $8.1^{b c} \pm 0.7$ & $6.5-8.5$ \\
\hline $\mathrm{EC}(\mu \mathrm{S} / \mathrm{cm})$ & $139^{\mathrm{a}} \pm 16$ & $272^{b} \pm 158$ & $117^{\mathrm{ac}} \pm 29$ & $142^{\mathrm{a}} \pm 13$ & $93.1^{\mathrm{c}} \pm 15$ & 1000 \\
\hline $\mathrm{DOC}(\mathrm{mg} / \mathrm{L})$ & $9.91^{\mathrm{a}} \pm 2.6$ & $17.4^{a} \pm 7.9$ & $10.8^{\mathrm{ab}} \pm 4.6$ & $9.67^{\mathrm{a}} \pm 2.0$ & $4.99^{b} \pm 2.1$ & \\
\hline $\mathrm{DN}(\mathrm{mg} / \mathrm{L})$ & $0.531^{\mathrm{ab}} \pm 0.21$ & $1.32^{b} \pm 1.1$ & $0.410^{\mathrm{ac}} \pm 0.11$ & $0.610^{\mathrm{bc}} \pm 0.21$ & $0.350^{\mathrm{d}} \pm 0.21$ & 1.5 \\
\hline $\mathrm{Na}(\mathrm{mg} / \mathrm{L})$ & $17.4^{\mathrm{a}} \pm 2.2$ & $22.9^{a} \pm 6.1$ & $19.6^{\mathrm{a}} \pm 4.4$ & $20.2^{\mathrm{a}} \pm 2.5$ & $10.6^{\mathrm{b}} \pm 3.1$ & \\
\hline $\mathrm{K}(\mathrm{mg} / \mathrm{L})$ & $4.83^{\mathrm{a}} \pm 1.2$ & $23.1^{b} \pm 25$ & $4.58^{\mathrm{ac}} \pm 2.0$ & $4.82^{\mathrm{a}} \pm 1.0$ & $3.11^{\mathrm{c}} \pm 0.5$ & \\
\hline $\mathrm{Mg}(\mathrm{mg} / \mathrm{L})$ & $2.76^{\mathrm{a}} \pm 1.3$ & $5.57^{a} \pm 3.8$ & $3.10^{\mathrm{a}} \pm 0.71$ & $3.32^{\mathrm{a}} \pm 0.61$ & $2.37^{\mathrm{b}} \pm 0.11$ & \\
\hline $\mathrm{Ca}(\mathrm{mg} / \mathrm{L})$ & $10.3^{\mathrm{a}} \pm 1.3$ & $20.1^{b} \pm 12$ & $12.7^{\mathrm{ab}} \pm 2.6$ & $11.3^{\mathrm{ab}} \pm 2.1$ & $7.3^{c} \pm 0.90$ & \\
\hline $\mathrm{Cr}(\mu \mathrm{g} / \mathrm{L})$ & $0.27^{\mathrm{a}} \pm 0.3$ & $0.31^{\mathrm{a}} \pm 0.4$ & $0.21^{\mathrm{ab}} \pm 0.2$ & $0.39^{a} \pm 0.5$ & $0.14^{\mathrm{b}} \pm 0.1$ & 50 \\
\hline $\mathrm{Fe}(\mu \mathrm{g} / \mathrm{L})$ & $450^{a} \pm 500$ & $1110^{b} \pm 900$ & $610^{\mathrm{ab}} \pm 600$ & $710^{\mathrm{ab}} \pm 600$ & $270^{a} \pm 200$ & 200 \\
\hline $\mathrm{Ni}(\mu \mathrm{g} / \mathrm{L})$ & $<0.8$ & $0.941^{\mathrm{a}} \pm 0.51$ & $<0.8$ & $2.21^{b} \pm 0.72$ & $1.46^{\mathrm{c}} \pm 0.49$ & 8.00 \\
\hline $\mathrm{Cu}(\mu \mathrm{g} / \mathrm{L})$ & $1.62^{\mathrm{ab}} \pm 0.7$ & $1.93^{\mathrm{ab}} \pm 0.9$ & $0.94^{\mathrm{a}} \pm 0.6$ & $2.18^{b} \pm 0.8$ & $1.17^{\mathrm{ab}} \pm 1.0$ & 20.0 \\
\hline $\mathrm{Zn}(\mu \mathrm{g} / \mathrm{L})$ & $130^{\mathrm{a}} \pm 60$ & $190^{\mathrm{ab}} \pm 300$ & $150^{\mathrm{a}} \pm 100$ & $200^{a b} \pm 200$ & $50^{\mathrm{b}} \pm 30$ & 70.0 \\
\hline $\operatorname{Sr}(\mu \mathrm{g} / \mathrm{L})$ & $120^{\mathrm{a}} \pm 10$ & $220^{a b} \pm 130$ & $140^{\mathrm{ab}} \pm 20$ & $140^{\mathrm{b}} \pm 20$ & $90^{\mathrm{c}} \pm 10$ & \\
\hline As $(\mu \mathrm{g} / \mathrm{L})$ & $1.74^{\mathrm{ab}} \pm 0.3$ & $1.89^{a} \pm 1.3$ & $1.69^{\mathrm{ab}} \pm 0.1$ & $1.83^{\mathrm{ab}} \pm 0.4$ & $1.47^{\mathrm{b}} \pm 0.3$ & 50 \\
\hline $\mathrm{Pb}(\mu \mathrm{g} / \mathrm{L})$ & $1.09^{\mathrm{ab}} \pm 0.5$ & $1.21^{a b} \pm 0.4$ & $1.01^{\mathrm{ab}} \pm 0.2$ & $1.11^{\mathrm{b}} \pm 0.3$ & $0.861^{\mathrm{a}} \pm 0.2$ & 2.50 \\
\hline
\end{tabular}

EU (2001), European Union; OECD (2007), Organisation for Economic Co-operation and Development: water quality guidelines for surface inland freshwater bodies

explained by two factors. The first is the buffering effect of the wetland through which water from the Kibos River enters the lake. A dense, approx. 3-km-wide belt of C. papyrus acts as a buffer and filter for incoming components. Numerous studies have shown that wetland plants can filter runoff water by increasing sedimentation and the uptake of contaminants, thereby protecting adjoining aquatic ecosystems (Verhoeven et al. 2006). Secondly, as shown by Okely et al. (2010) and indicated in Fig. 1, the waterbody at the KK site is rather isolated from the KM site by lake currents: waterborne materials dispersed from Kisumu City site are transported along a narrow stream of currents near the northern shoreline. Accordingly, materials entering the lake at KM will have limited horizontal mixing with water at KK. The mean concentrations of dissolved components at $\mathrm{AB}$ and $\mathrm{MN}$ sites were comparable, but higher than at RS, underlining other sources within the gulf, apart from Kisumu City. Runoff from rural farmlands adjacent to the lake could be a contributing source of contaminants (Lung'ayia et al. 2001). The high level of dissolved $\mathrm{Ni}, \mathrm{Cu}$ and $\mathrm{Zn}$ at $\mathrm{MN}$ is also mirrored by the elevated levels in the surface sediment (especially for $\mathrm{Ni}$ and $\mathrm{Zn}$ ) (Table 2). We therefore assume a diffuse contamination of dissolved metals rather than a point source of the respective metals.

DN and DOC also varied distinctly between the sites within Winam Gulf and the RS site. Contamination of the lake

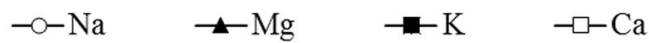

a

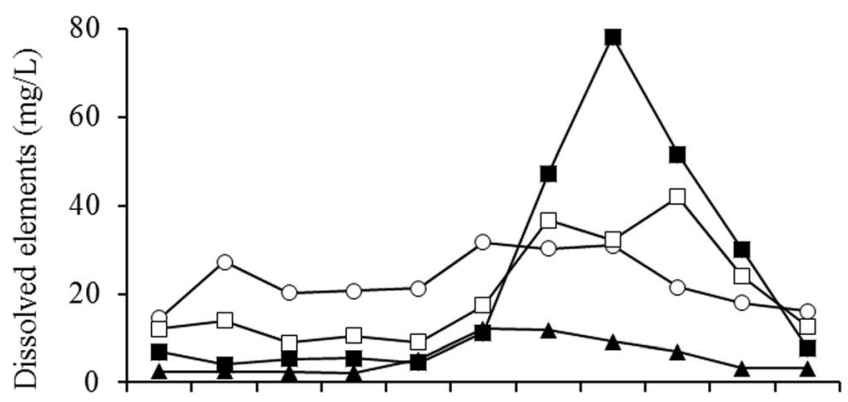

Sep. Oct. Nov.Dec. Jan. Feb. Mar. Apr. May Jun. Jul.

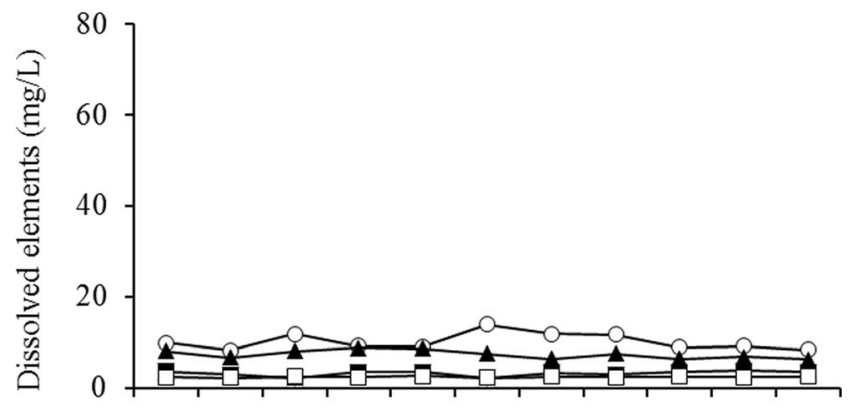

Sep. Oct. Nov. Dec. Jan. Feb. Mar. Apr. May Jun. Jul.

Fig. 2 Temporal variation of major elements in surface water at Kisumu City (a) and Rusinga Island (b) sampling sites 
with DN from the catchment is reflected in the high levels of $\mathrm{DN}$ in the gulf: $\mathrm{KM}(1.32 \pm 1.1 \mathrm{mg} / \mathrm{L}), \mathrm{MN}(0.601 \pm 0.23 \mathrm{mg} /$ $\mathrm{L})$ and $\mathrm{AB}(0.523 \pm 0.19 \mathrm{mg} / \mathrm{L})$ compared with $\mathrm{RS}(0.347 \pm$ $0.17 \mathrm{mg} / \mathrm{L}$ ). Nitrogen enrichment of Lake Victoria stems mainly from sewage effluents and river inputs that drain agricultural lands and discharges into the gulf (Nyilitya et al. 2016). The mean DOC values in the four gulf sites (9.67$17.4 \mathrm{mg} / \mathrm{L})$ were much higher than at RS $(4.99 \mathrm{mg} / \mathrm{L})$. Sobek et al. (2007) reported a median value of $5.71 \mathrm{mg} / \mathrm{L}$ from 7514 lakes from six continents, which is comparable with our findings from the main Lake Victoria body (RS), but lower than the mean values in Winam Gulf. In lakes, DOC can be autochthonous and/or allochthonous (Sobek et al. 2007). The results of our study can be explained by two factors. First, wetland vegetation around the inshore bays and gulfs of Lake Victoria is dominated by a highly productive emergent $\mathrm{C}_{4}$ sedge (C. papyrus) which generates large quantities of organic carbon under the favourable conditions of high solar insolation and abundant water (Loiselle et al. 2010). Second, intensive land use in the catchment may act as a significant source of organic carbon (Njiru et al. 2008). With regard to the spatial distribution of DOC in Lake Victoria, Loiselle et al. (2010) observed a limited exchange of organic carbon between Winam Gulf and the main lake, where only one-third of the DOC released into the lake at the gulf reached the open water. This is mirrored in our finding that DOC at $\mathrm{KM}$ was at least three times higher than at RS. In Winam Gulf, however, the nuisance floating macrophyte - the water hyacinth $E$. crassipes - dominated the water surface and was present during our study; its role in DOC cycling should be investigated in future studies. DOC is crucial in the chemistry of freshwater because it complexes heavy metals, making them less bioavailable to aquatic organisms (Winch et al. 2002). The
DOC association with $\mathrm{Fe}$ complexation in the water (Knocke et al. 1992) is mirrored in the spatial distribution of dissolved $\mathrm{Fe}$ in our study.

Despite the spatio-temporal variations in the concentrations of dissolved major and trace elements in Lake Victoria, most of these parameters were below the water quality guidelines for surface inland waters, e.g. (EU 2001; OECD 2007) as indicated in Table 1. The levels of dissolved $\mathrm{Fe}$ and $\mathrm{Zn}$ were, however, higher than the recommended guidelines.

\section{Trace elements in sediment}

Table 2 summarizes the concentrations of organic matter and trace elements in the surface sediment. The order of concentration of trace elements measured in the sediment was $\mathrm{Sr}>\mathrm{Zn}$ $>\mathrm{Pb}>\mathrm{Cu}>\mathrm{Cr}>\mathrm{Ni}>\mathrm{As}>\mathrm{Ag}>\mathrm{Cd}$. When interpreting the results, note that the digestion method used is considered to be 'pseudo-total' (Davidson 2013), so the actual concentration of the trace elements in sediment could be as much as 10-30\% underestimated. The highest mean values for $\mathrm{Cr}, \mathrm{Cu}, \mathrm{Zn}, \mathrm{Ag}$, $\mathrm{Cd}$ and $\mathrm{Pb}$ were recorded at the $\mathrm{KM}$ site, with $\mathrm{MN}$ having the highest mean value for Ni, As and $\mathrm{Sr}(P<0.05)$. The temporal trends indicate a sharp increase in the levels of $\mathrm{Cu}$ (fivefold), $\mathrm{Zn}$ (threefold), $\mathrm{Cd}$ (ninefold) and $\mathrm{Pb}$ (ninefold) from March to April at the Kisumu City site (Fig. 3). Temporal variation was not prominent at the other four sampling sites, as reflected in the smaller standard deviations of the means compared with KM (Table 2).

As was the case with the increase of dissolved elements in water, the contamination of the surface sediment at KM due to the impact of Kisumu City is evidenced in the much higher mean values of trace elements, which showed temporal variation during the study. This is attributed to both point and
Table 2 Concentration (mean $\pm \mathrm{SD}$ ) of elements ( $\mathrm{mg} / \mathrm{kg}$ dry weight) and organic matter $(\mathrm{OM})$ content $(\%)$ in surface sediment in the sampling sites as compared with literature data. Italic text: site with the highest mean concentrations for each parameter. Mean values followed by same superscript letters for each parameter do not differ significantly in the current study $(P>0.05)$

\begin{tabular}{|c|c|c|c|c|c|c|c|}
\hline Parameter & $\mathrm{AB}(n=30)$ & $\mathrm{KM}(n=33)$ & $\mathrm{KK}(n=27)$ & $\mathrm{MN}(n=24)$ & $\operatorname{RS}(n=33)$ & TEC & Shale \\
\hline $\mathrm{OM}$ & $9.39^{\mathrm{a}} \pm 4.6$ & $9.51^{a} \pm 5.5$ & $6.23^{b} \pm 3.0$ & $2.37^{\mathrm{c}} \pm 1.2$ & $3.83^{\mathrm{d}} \pm 2.2$ & & \\
\hline $\mathrm{Cr}$ & $27.9^{\mathrm{a}} \pm 19$ & $56.9^{b} \pm 21$ & $41.8^{c} \pm 17$ & $26.7^{\mathrm{a}} \pm 13$ & $28.7^{\mathrm{a}} \pm 21$ & 43.5 & 42 \\
\hline $\mathrm{Ni}$ & $15.9^{\mathrm{a}} \pm 9.9$ & $15.9^{\mathrm{a}} \pm 7.1$ & $19.1^{\mathrm{a}} \pm 8.6$ & $29.0^{b} \pm 11$ & $17.3^{\mathrm{a}} \pm 6.9$ & 22.7 & 18 \\
\hline $\mathrm{Cu}$ & $28.2^{\mathrm{a}} \pm 16$ & $60.1^{b} \pm 63$ & $29.4^{\mathrm{a}} \pm 14$ & $23.7^{\mathrm{a}} \pm 11$ & $46.9^{b} \pm 35$ & 35.8 & 45 \\
\hline $\mathrm{Zn}$ & $81.6^{\mathrm{a}} \pm 39$ & $295^{b} \pm 229$ & $107^{c} \pm 39$ & $105^{\mathrm{ac}} \pm 39$ & $94.1^{\mathrm{ac}} \pm 29$ & 121 & 95 \\
\hline As & $2.69^{\mathrm{ad}} \pm 5.4$ & $4.98^{b} \pm 4.1$ & $2.12^{\mathrm{a}} \pm 1.4$ & $6.19^{c} \pm 3.1$ & $1.19^{\mathrm{d}} \pm 0.4$ & 9.79 & 4.7 \\
\hline $\mathrm{Sr}$ & $60.1^{\mathrm{a}} \pm 19$ & $71.1^{\mathrm{a}} \pm 49$ & $117^{b} \pm 129$ & $603^{c} \pm 193$ & $426^{\mathrm{d}} \pm 148$ & & 300 \\
\hline $\mathrm{Ag}$ & $0.038^{a} \pm 0.02$ & $1.36^{b} \pm 1.7$ & $0.031^{\mathrm{a}} \pm 0.01$ & $0.037^{\mathrm{a}} \pm 0.02$ & $0.023^{\mathrm{c}} \pm 0.01$ & 1.0 & 0.1 \\
\hline $\mathrm{Cd}$ & $0.193^{\mathrm{a}} \pm 0.25$ & $0.556^{b} \pm 0.72$ & $0.091^{\mathrm{c}} \pm 0.05$ & $0.294^{b} \pm 0.06$ & $0.119^{\mathrm{ac}} \pm 0.05$ & 0.99 & 0.3 \\
\hline $\mathrm{Pb}$ & $6.82^{\mathrm{a}} \pm 3.4$ & $195^{b} \pm 273$ & $15.4^{\mathrm{c}} \pm 5.8$ & $27.9^{d} \pm 10$ & $13.3^{c} \pm 7.5$ & 35.8 & 20 \\
\hline
\end{tabular}

TEC - Consensus-based threshold effect concentration: Macdonald et al. (2000); Simpson et al. (2013)

Shale - Earth's crust geochemical average background value: Turekian and Wedepohl (1961); Alloway (2013) 

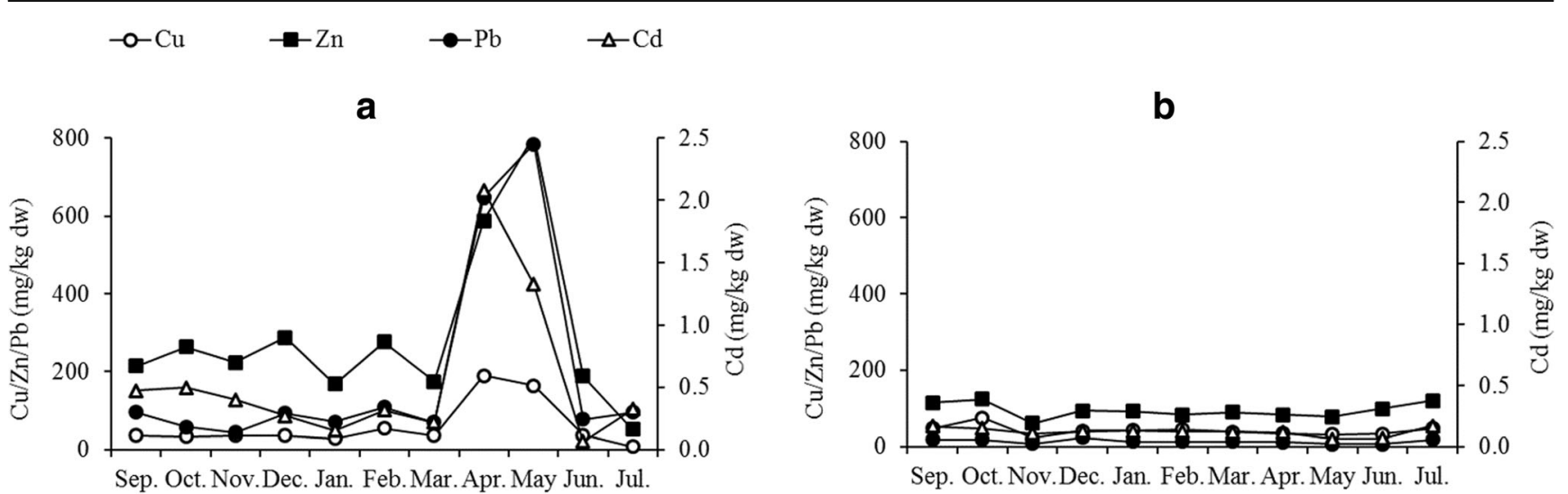

Fig. 3 Temporal variation of selected heavy metals in surface sediment at Kisumu City (a) and Rusinga Island (b) sampling sites

diffuse sources of contamination (Awange and Obera 2007; Kobingi et al. 2009; Kundu et al. 2017). The spatial distinctions in trace element levels in the surface sediment probably reflect the limited exchange of water-borne materials between the study sites. Njuru et al. (2013) observed that contaminants entering the gulf through river inflows and municipal sources are largely retained there, with minimal exchange into the main lake. Moreover, Okely et al. (2010) showed that localized water currents limited the transport of contaminants within the gulf (Fig. 1). The elevated levels of trace elements in KM surface sediment coincided with the long rain season (March-May), indicating that storm water surface runoff through the city and input through the Kisat River played a major role in the sediment characteristics here. As indicated in supplementary material (SM) Table 3, $\mathrm{Cu}$ and $\mathrm{Zn}$ had the highest positive correlation with $\mathrm{OM}\left(r_{\mathrm{s}}=0.53\right.$ for $\mathrm{Cu}$ and 0.52 for $\mathrm{Zn}$ ) and showed a significant high positive correlation with each other $\left(r_{\mathrm{s}}=0.72\right)$. This indicates that they are probably accumulated simultaneously from runoff and wastewater inputs. Skwierawski and Sidoruk (2014) concluded that high correlations among metals in freshwater sediment point to shared pollution and sediment enrichment sources. Cd occurs in phosphate fertilizer to varying degrees and in agricultural soils where phosphate fertilizer is applied (Roberts 2014). Runoff from agricultural lands is therefore a potential source of Cd contamination in Lake Victoria. In contrast, a potential source of $\mathrm{Pb}$ contamination at Kisumu City is the use of leadbased paints, which are yet to be phased out in Kenya (Kessler 2014). Finally, Pb-based fuel was widely used in Kenya before being phased out in the last decade, and roadside soils in Kisumu City were contaminated by $\mathrm{Pb}$ (Makokha et al. 2008). Runoff from contaminated roadside soils and open garages (with $\mathrm{Pb}$-based paint scrapings) are therefore potential sources of $\mathrm{Pb}$ contamination in Lake Victoria. Most of the trace elements showed significant positive correlations with the organic matter content of the sediment (SM Table 3). $\mathrm{Cu}, \mathrm{Zn}$ and $\mathrm{Ag}$ showed medium positive correlations with OM, while Cr, As and $\mathrm{Cd}$ showed weak positive correlations. $\mathrm{Ni}$ and $\mathrm{Pb}$ showed no significant correlations with $\mathrm{OM}$, while $\mathrm{Sr}$ is the only element that had a significant negative correlation with OM. Lake Victoria is eutrophic (Kundu et al. 2017) and, as noted by Otachi et al. (2014), nitrates play a role in reducing Srorganic matter complexes; this can partly explain the negative correlation we found in our study.

The distribution of trace elements showed no significant variation between the three sediment layers (surface ' $0 \mathrm{~cm}$ ', ' $-15 \mathrm{~cm}$ ', ' $-25 \mathrm{~cm}$ ') at the sampling sites, except for selected elements at the Kisumu City site. As shown in Fig. 4, the levels of $\mathrm{Cu}, \mathrm{Zn}, \mathrm{Pb}$ and $\mathrm{Cd}$ decreased gradually, with significantly higher concentrations in the surface layer than at $25 \mathrm{~cm}(P<0.05)$. The Ag concentration was higher in surface sediment than both at -15 and $-25 \mathrm{~cm}(P<0.05)$. Some studies have shown that anthropogenic pollutants, including heavy metals, have a vertical distribution pattern with higher levels in the top versus deeper layers. Skwierawski and Sidoruk (2014) found very high $\mathrm{Cr}, \mathrm{Zn}$ and $\mathrm{Pb}$ concentrations in the uppermost sediment layer $(0-10 \mathrm{~cm})$ in the region of Plociduga reservoir (Poland), which received storm water, whereas Yang et al. (2010) reported that the greatest concentrations of $\mathrm{Cu}, \mathrm{Zn}, \mathrm{Cd}$ and $\mathrm{Pb}$ in an urban lake (China) were found in the surface sediment, with a rapid decrease between 0 - and 15-cm layers, and little change in the 15-25-cm layers. The 0-10-cm layer of inshore sediment at Lake Victoria represents approx. 15 years (Ramlal et al. 2003). Accordingly, the surface sediment in our study $(0-3 \mathrm{~cm})$ has been deposited within the last 15 years. This implies that the input of $\mathrm{Cu}, \mathrm{Zn}$, $\mathrm{Ag}, \mathrm{Cd}$ and $\mathrm{Pb}$ into the lake at Kisumu City has risen significantly over the past 15 years. Ag is of interest because there is very little information on its levels in Kenyan aquatic ecosystems. According to WHO (2002), emissions from smelting operations, manufacture and disposal of certain photographic and electrical supplies were among the major anthropogenic sources of silver in the biosphere. Recent studies such as McGillicuddy et al. (2017) and Yuan et al. (2018) have shown that the usage of silver nano-particles has increased in numerous consumer products such as textiles, medical products, domestic appliances, food containers, cosmetics, paints and nano-functionalised plastics in many parts of the world. 

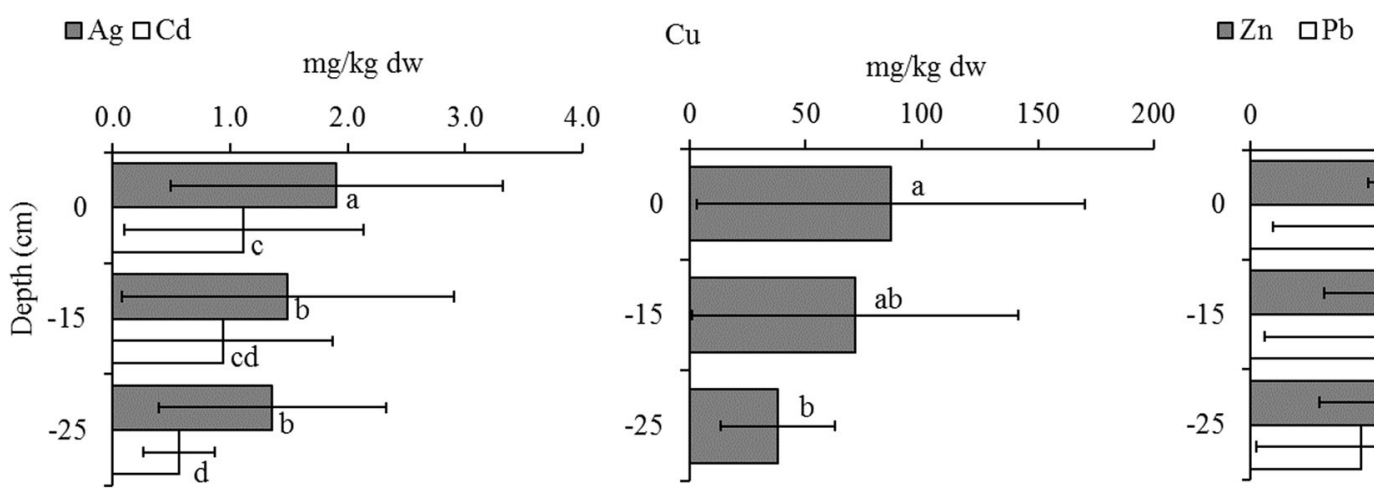

Fig. 4 Concentrations of selected heavy metals in surface, $-15-\mathrm{cm}$ and $-25-\mathrm{cm}$ sediment layers at the Kisumu City sampling site. Error bars (mean \pm SD) for each element followed by the same letters do not differ significantly $(P>0.05)$. For each sediment layer, $n=9$

These products release silver into aquatic ecosystems through wastewater discharge, which raises health and environmental concerns. This recent trend in the use of silver probably explains why Ag levels were elevated in surface sediment at the Kisumu City cite, where municipal wastewater effluent enters the lake.

Comparing the metal contents of surface sediment from this study with previous studies reveals that the heavy metal levels have continued to rise at KM, with at least a twofold increase in $\mathrm{Cu}(60.0 \mathrm{mg} / \mathrm{kg}), \mathrm{Zn}(295 \mathrm{mg} / \mathrm{kg})$ and $\mathrm{Pb}(195$ $\mathrm{mg} / \mathrm{kg}$ ) within the last three decades. Onyari and Wandiga (1989) in the 1985 survey reported mean values for $\mathrm{Cu}$ (24. $8 \mathrm{mg} / \mathrm{kg}), \mathrm{Zn}(144 \mathrm{mg} / \mathrm{kg})$ and $\mathrm{Pb}(25.5 \mathrm{mg} / \mathrm{kg})$, whereas Mwamburi and Oloo (1996) reported corresponding values of $30 \mathrm{mg} / \mathrm{kg}(\mathrm{Cu}), 136.4 \mathrm{mg} / \mathrm{kg}(\mathrm{Zn})$ and $122.7 \mathrm{mg} / \mathrm{kg}(\mathrm{Pb})$. In Mwanza Gulf, Kishe-Machumu and Machiwa (2003) reported even lower values: $\mathrm{Cu}(21.6 \mathrm{mg} / \mathrm{kg}), \mathrm{Zn}(36.4 \mathrm{mg} / \mathrm{kg})$ and $\mathrm{Pb}(29.6 \mathrm{mg} / \mathrm{kg})$. Ag levels have nearly doubled in the last 15 years since Ochieng et al. (2006) reported mean values 0.8 $\mathrm{mg} / \mathrm{kg}$ at Kisumu City from samples taken in 2001, compared with $1.36 \mathrm{mg} / \mathrm{kg}$ from our study. Our results from the city outskirts (KK), the mid-gulf sites ( $\mathrm{AB}$ and $\mathrm{MN}$ ) and main lake (RS) are comparable with the findings from the previous studies.

Evaluating the sediment quality with various toxicity parameters highlights the degraded ecological status of the lake with regard to trace element contamination in the gulf. The mean values of $\mathrm{Cr}, \mathrm{Cu}, \mathrm{Zn}, \mathrm{Ag}$ and $\mathrm{Pb}$ in the surface sediment at KM (Table 2) surpassed the TEC limits (MacDonald et al. 2000; Simpson et al. 2013). Further analysis indicates that $45.5 \%$ of the samples analysed for $\mathrm{Cr}(12-84 \mathrm{mg} / \mathrm{kg})$ surpassed the PEL of $68 \mathrm{mg} / \mathrm{kg}$ (de Deckere et al. 2011), while for $\mathrm{Cu}(14-259 \mathrm{mg} / \mathrm{kg}), 15.2 \%$ of the samples surpassed the SEL of $110 \mathrm{mg} / \mathrm{kg}$. For Zn (46-1093 mg/kg), 18.2\% of the samples were above the PEL of $459 \mathrm{mg} / \mathrm{kg}$ (MacDonald et al. 2000). $\mathrm{Pb}$ ranged from 28 to $1188 \mathrm{mg} / \mathrm{kg}$ with a mean value of $195 \mathrm{mg} / \mathrm{kg}$, which is higher than the SEL of $167 \mathrm{mg} / \mathrm{kg}$ (de Deckere et al. 2011). Note, however, that the mean values for all metals measured at the other four sampling sites were below the TEC limits, except for Ni at Mainuga (MN) and $\mathrm{Cu}$ at Rusinga Island (RS). $8.3 \%$ of the MN samples had Ni concentrations above the PEL of $48.6 \mathrm{mg} / \mathrm{kg}$ (MacDonald et al. 2000; de Deckere et al. 2011). These findings indicate that the sediment at $\mathrm{MN}$ is moderately polluted with $\mathrm{Ni}$, while $\mathrm{KM}$ is moderately polluted with $\mathrm{Cr}, \mathrm{Zn}, \mathrm{Ag}$ and $\mathrm{Cd}$ and severely polluted with $\mathrm{Cu}$ and $\mathrm{Pb}$. The mean values for arsenic, in contrast, were only minimally elevated in all sampling sites and were within the recommended sediment quality guidelines. This indicates that these values are probably the background levels and that there is currently no significant anthropogenic input of arsenic at the study sites.

\section{Trace element accumulation in macrophytes}

\section{V. cuspidata}

A total of 63 specimens of $V$. cuspidata were sampled: 14 each from $\mathrm{AB}$ and KM, 11 from KK and 12 each from $\mathrm{MN}$ and $\mathrm{RS}$ (Table 3). Ag was below the detection limit $(0.015 \mathrm{mg} / \mathrm{kg})$ in the stems at all sampling sites. Cd was also below the detection limit $(0.005 \mathrm{mg} / \mathrm{kg})$ in stem tissue except at MN. The roots and stems accumulated trace elements in the order: $\mathrm{Zn}$ $>\mathrm{Sr}>\mathrm{Cu}>\mathrm{Pb}>\mathrm{Cr}>\mathrm{Ni}>\mathrm{As}>\mathrm{Cd}>\mathrm{Ag}$. The concentrations were significantly higher in the roots than in the stems except for $\mathrm{Sr}$ at $\mathrm{RS}(P<0.05)$. The spatial distribution of trace elements in the sediment is mirrored in the roots of $V$. cuspidata, with plants from the main lake site (RS) having the lowest concentrations of $\mathrm{Cr}, \mathrm{Ni}, \mathrm{As}, \mathrm{Sr}, \mathrm{Ag}, \mathrm{Cd}$ and $\mathrm{Pb}$ compared with the four sites in Winam Gulf. Contamination of the lake at the Kisumu City site with $\mathrm{Cu}, \mathrm{Zn}, \mathrm{Ag}, \mathrm{Cd}$ and $\mathrm{Pb}$, and at the Mainuga site with $\mathrm{Ni}$ and $\mathrm{Cd}$ is well mirrored in the roots of $V$. cuspidata. Figure 5 depicts the correlations between plant and sediment concentrations for $\mathrm{Ni}, \mathrm{Zn}, \mathrm{Ag}$ and $\mathrm{Pb}$; $\mathrm{SM}$ Figure 1 depicts the correlations for $\mathrm{Cu}$ and $\mathrm{Cd}$. The $\mathrm{BCF}$ values for $V$. cuspidata stems and roots in relation to the sediment were below 1 for all elements (SM table 4).

The partitioning of trace elements, with higher accumulation in the roots than the stems, agrees with findings from 


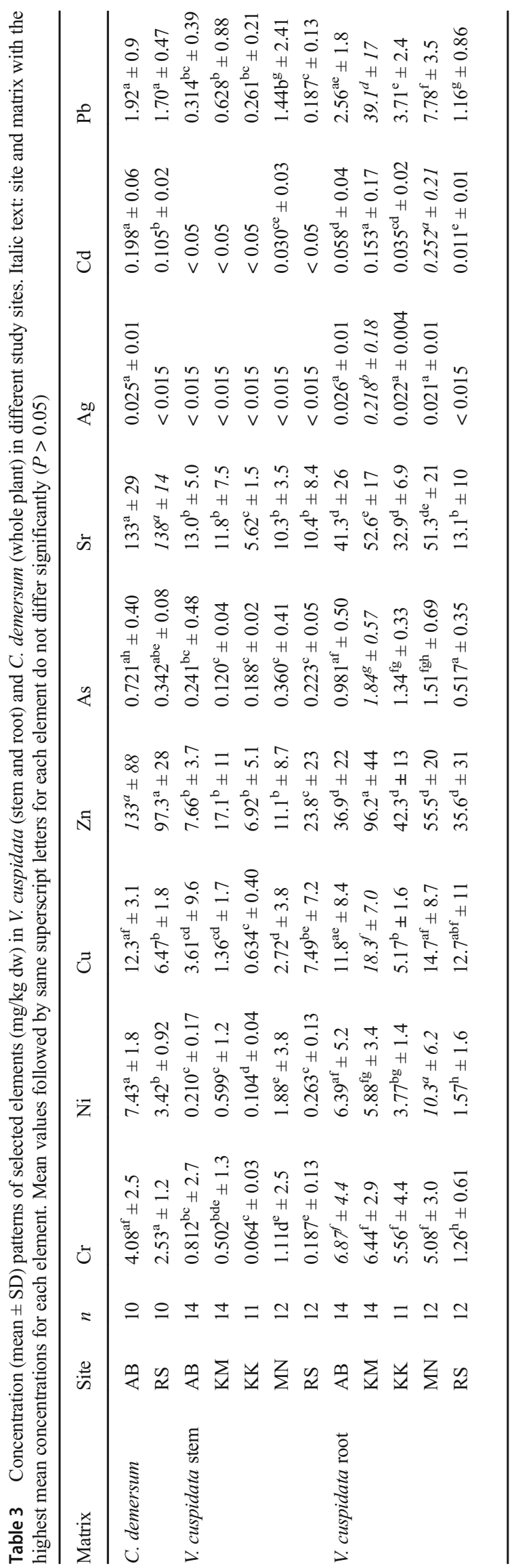

other studies on emergent macrophytes (Brankovic et al. 2015; Galal et al. 2017). These plants take up and accumulate trace elements in the roots but restrict their translocation to the shoot and are regarded as excluders. Such metal excluders maintain a low shoot metal concentration over a wide range of substrate/soil concentrations (Baker 1981). This seems to be a protective measure. For instance, plants trap arsenate below ground to prevent access to above-ground reproductive tissues in order to prevent possible mutagenic consequences (Dhankher 2005).

Studies on trace element uptake and accumulation in $V$. cuspidata are scarce. Our findings differ considerably from those of Galal et al. (2017) on heavy metal accumulation in V. cuspidata from Ismailia Canal, Egypt. There, V. cuspidata roots accumulated higher levels of Ni (572$1059 \mathrm{mg} / \mathrm{kg}), \mathrm{Cu}(452-1787 \mathrm{mg} / \mathrm{kg}), \mathrm{Zn}(391-783 \mathrm{mg} / \mathrm{kg})$, $\mathrm{Cd}(23.4-75.8 \mathrm{mg} / \mathrm{kg})$ and $\mathrm{Pb}(23.3-195 \mathrm{mg} / \mathrm{kg})$ than in Lake Victoria: $\mathrm{Ni}(1.57-10.3 \mathrm{mg} / \mathrm{kg}), \mathrm{Cu}(5.17-18.3 \mathrm{mg} / \mathrm{kg}), \mathrm{Zn}$ (35.6-96.2 mg/kg), Cd (0.011-0.258 mg/kg) and $\mathrm{Pb}(1.16$ $39.1 \mathrm{mg} / \mathrm{kg}$ ). Comparing the trace element contents of surface sediment in the two aquatic systems shows that, except for $\mathrm{Cu}$ and Cd, Lake Victoria had higher levels of most trace elements than Ismailia Canal. Since the respective concentrations in the sediments of the two systems cannot explain the highly contrasting findings on the concentrations in V. cuspidata, further investigations are warranted. As no previous studies on arsenic, $\mathrm{Sr}$ or $\mathrm{Ag}$ accumulation in V. cuspidata are available, only comparisons with other emergent macrophytes are possible. For instance, Favas et al. (2012) recorded mean arsenic concentrations of $0.90 \mathrm{mg} / \mathrm{kg}$ in the roots and rhizomes of Typha latifolia L. in Portugal, which is comparable with the range of means in our sampling sites $(0.517-1.84 \mathrm{mg} / \mathrm{kg}$ ). Yuan et al. (2018), in experimental treatments in the USA, recorded $4.49-8.87 \mathrm{mg} / \mathrm{kg} \mathrm{Ag}$ in the root tissue of Juncus effusus L., which is much higher than our findings $(0.02-0.54 \mathrm{mg} / \mathrm{kg})$.

\section{C. demersum}

C. demersum was found only at the Asembo Bay (AB) and Rusinga Island sites (RS), and 10 specimens were taken from each site. The elemental concentrations are listed in Table 3. $\mathrm{Ag}$ was below detection limits in $C$. demersum at RS, but measurable in samples from $\mathrm{AB}$. The plant accumulated the measured trace elements in the order: $\mathrm{Sr}>\mathrm{Zn}>\mathrm{Cu}>\mathrm{Ni}>\mathrm{Cr}$ $>\mathrm{Pb}>\mathrm{As}>\mathrm{Cd}>\mathrm{Ag}$. The plants at $\mathrm{AB}$ had higher concentrations of $\mathrm{Ni}, \mathrm{Cu}, \mathrm{Ag}$ and $\mathrm{Cd}$ than those at $\mathrm{RS}$; however, except for $\mathrm{Ag}$, those concentrations did not directly correspond to their respective levels in the water or sediment. The BCFs in relation to water were in the order: $\mathrm{Cr}>\mathrm{Ni}>\mathrm{Cu}>\mathrm{Pb}$ $>\mathrm{Zn}>\mathrm{Sr}>\mathrm{As}$ (SM table 4). BCF was not calculated for Ag and $\mathrm{Cd}$ because they were below detection limits in water. Unlike V. cuspidata, which did not accumulate any of the trace 

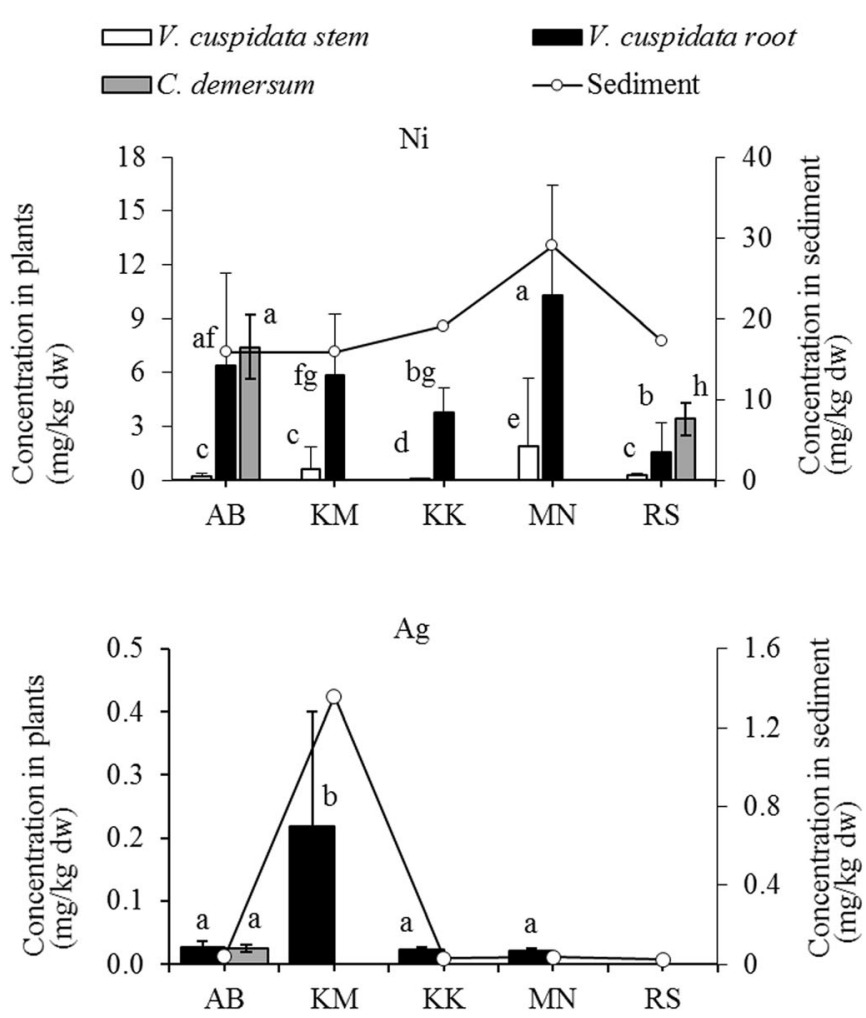

Fig. 5 Concentration patterns of selected elements in V. cuspidata (stem and root) and C. demersum (whole plant) and the corresponding surface sediment content in different sampling sites. Surface sediment contents for $\mathrm{Ni}, \mathrm{Ag}$ and $\mathrm{Pb}$ are indicated on the secondary axes. Error bars (mean \pm

elements higher than the levels in the sediment, $C$. demersum showed bioaccumulation: $\mathrm{Zn}(\mathrm{BCF}=1.03$ at $\mathrm{RS}$ and 1.63 at $\mathrm{AB}), \operatorname{Sr}(\mathrm{BCF}=2.21$ at $\mathrm{AB})$ and $\mathrm{Cd}(\mathrm{BCF}=1.03$ at $\mathrm{AB})$ in relation to the sediment. The concentrations (mean values) of $\mathrm{Ni}(5.43 \mathrm{mg} / \mathrm{kg}), \mathrm{Cu}(9.39)$ and $\mathrm{Pb}(1.81 \mathrm{mg} / \mathrm{kg})$ were much lower than in other studies. Kastratovic et al. (2014) recorded $11.2 \mathrm{mg} / \mathrm{kg}, 16.85 \mathrm{mg} / \mathrm{kg}$ and $7.48 \mathrm{mg} / \mathrm{kg}$ for the three elements in Skador, Montenegro, while the corresponding values in a eutrophic lake in China were $70 \mathrm{mg} / \mathrm{kg}, 32 \mathrm{mg} / \mathrm{kg}$ and 83 $\mathrm{mg} / \mathrm{kg}$ (Xing et al. 2013). High accumulation of $\mathrm{Sr}$ (96.1-184 $\mathrm{mg} / \mathrm{kg}$ ) and a high BCF in relation to water (1276) in our study are higher than the findings of Kastratovic et al. (2014), who recorded a mean value of $22.9 \mathrm{mg} / \mathrm{kg}$ and BCF of 1.5 .

$V$. cuspidata and $C$. demersum from the same sampling sites (AB and RS) showed a comparable accumulation of certain trace elements and a clear distinction in the accumulation of others. All stem concentrations except As were significantly higher in $C$. demersum than in $V$. cuspidata $(P<0.05)$. While the levels of $\mathrm{Cr}, \mathrm{Ni}, \mathrm{Cu}, \mathrm{As}, \mathrm{Ag}$ and $\mathrm{Pb}$ were not significantly different between $V$. cuspidata roots and $C$. demersum stems, the concentrations of $\mathrm{Zn}, \mathrm{Sr}$ and $\mathrm{Cd}$ were significantly higher in the latter than in the former $(P<0.05)$. Macrophytes immersed in the water column have faster mass transfer rates, and a more poorly developed epidermal lipophilic cuticle, than emergent macrophytes. This means they
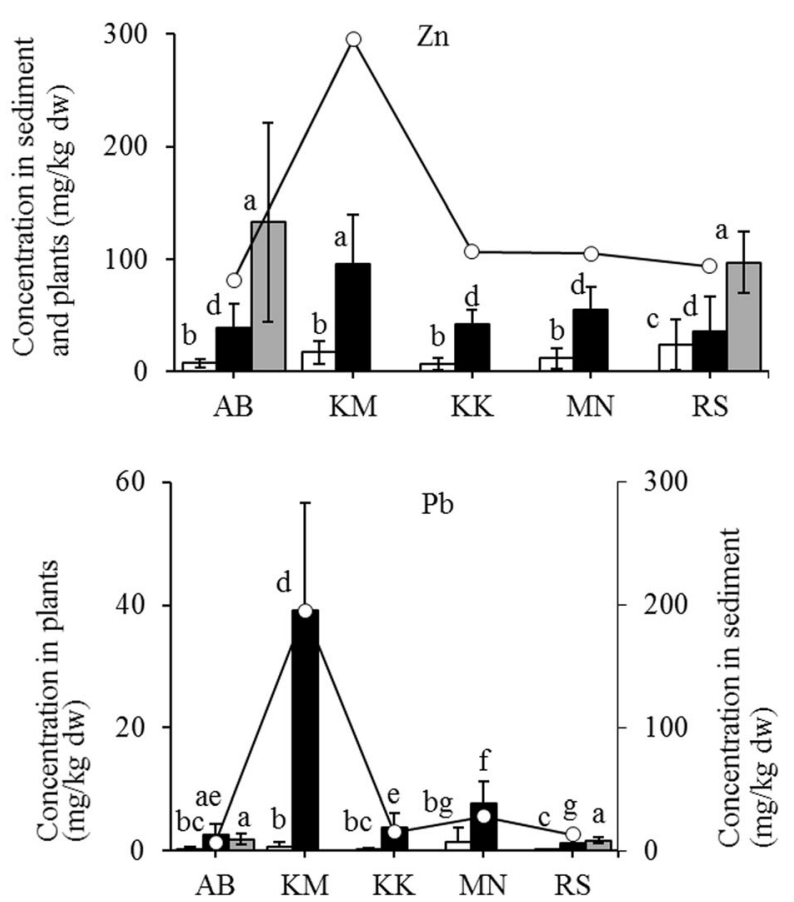

SD) for elements in plant tissue followed by same letters do not differ significantly $(P>0.05)$. C. demersum: $\mathrm{AB}$ and $\mathrm{RS}(n=10)$; V. cuspidata: $\mathrm{AB}$ and $\mathrm{KM}(n=14) ; \mathrm{KK}(n=11): \mathrm{MN}$ and $\mathrm{RS}(n=12)$

have an enhanced uptake of metal(loid)s via their stems and leaves (Xing et al. 2010). Moreover, C. demersum is rootless, but the leaves are finely divided into a root like appearance, exposing a large surface area of the plant to water (high surface area to volume ratio) and thereby enhancing heavy metal uptake from the water column ( $\mathrm{Li}$ et al. 2015). At the same time, the mobility and bioavailability of elements in the sediment can be very low, hence restricting uptake by emergent macrophytes (Lowry et al. 2012). As discussed above, V. cuspidata, like most emergent plants, restricts the acropetal transport of trace metals, explaining the very low levels these metals in their stems.

\section{Conclusion}

The spatio-temporal distribution of metals in the water and surface sediment paints a picture of anthropogenic contamination in Winam Gulf. The impact of Kisumu City on the lake is evident by comparatively high mean values of dissolved components in the water and trace elements in the surface sediment, which showed temporal variation, with the highest values coinciding with the rainy season (March-May). Generally, the surface sediments in the gulf are moderately polluted with $\mathrm{Cr}, \mathrm{Ni}, \mathrm{Cu}, \mathrm{Zn}, \mathrm{Ag}$ and $\mathrm{Pb}$, with severe $\mathrm{Cu}$ and 
$\mathrm{Pb}$ pollution occurring at the Kisumu City site. In addition, surface sediment $(0-3 \mathrm{~cm})$, representing sediment that has been deposited within the last 15 years, had significantly higher levels of $\mathrm{Cu}, \mathrm{Zn}, \mathrm{Ag}, \mathrm{Cd}$ and $\mathrm{Pb}$ than deeper layers at $\mathrm{KM}$, pointing to recent anthropogenic pollution.

Apart from $\mathrm{Zn}, \mathrm{Sr}$ and $\mathrm{Cd}$, which were higher in $C$. demersum, the concentrations of most elements were comparable between $C$. demersum stems and the roots of $V$. cuspidata. The spatial distribution of trace elements in the water and sediment is best mirrored in the roots of V. cuspidata, which accumulated $\mathrm{Cr}, \mathrm{Ni}, \mathrm{Cu}, \mathrm{Zn}, \mathrm{Ag}, \mathrm{Cd}$ and $\mathrm{Pb}$ corresponding with their levels in the water and sediment. $V$. cuspidata is considered an excluder because it has a poor ability to transport trace elements from the roots to the stem. Hence, using the shoots as fodder does not pose a significant risk to livestock. Nonetheless, considering that the concentrations of $\mathrm{Cr}, \mathrm{Ni}, \mathrm{Cu}, \mathrm{Zn}, \mathrm{Ag}$ and $\mathrm{Pb}$ in surface sediment surpassed the consensus-based threshold effect concentrations in Winam Gulf, their levels in the fauna of the lake, which serve as food for the local population, should be subject to indepth investigations.

Acknowledgements Open access funding provided by University of Vienna. We wish to thank Maseno University, Kenya, for providing laboratory space, facilities and technical assistance. Michael Stachowitsch is thanked for reviewing the English of this article.

Funding information Parts of this study were financially supported by the Austrian Agency for International Cooperation in Education and Research (OeAD-GmbH) through a scholarship award within the Austrian Partnership Program in Higher Education and Research for Development (APPEAR).

Open Access This article is distributed under the terms of the Creative Commons Attribution 4.0 International License (http:// creativecommons.org/licenses/by/4.0/), which permits unrestricted use, distribution, and reproduction in any medium, provided you give appropriate credit to the original author(s) and the source, provide a link to the Creative Commons license, and indicate if changes were made.

\section{References}

Akwiri O, Raburu PO, Okeyo OJB, Francis R, Onyangore FO (2016) Concentration of selected heavy metals in sediments and liver of wild African catfish (Clarias gariepinus) in Lake Kanyaboli, Kenya. Annu Res Rev Biol 11:1-8. https://doi.org/10.9734/ ARRB/2016/28471

Alloway BJ (2013) Environmental Pollution. In: Heavy metals in soils: trace metals and metalloids in soils and their bioavailability, vol 22 , 3rd edn. Springer Science+Business Media, Dordrecht. https://doi. org/10.1007/978-94-007-4470-7_4

Alonso CML, Sánchez Trujillo I, Alonso EV, García de Torres A, Pavón J (2013) Bioavailability of heavy metals in water and sediments from a typical Mediterranean Bay (Málaga Bay, Region of Andalucía, Southern Spain). Mar Pollut Bull 76(1-2):427-434. https://doi.org/ 10.1016/j.marpolbul.2013.08.031
Aras S, Aydin S, Aksoy D, Dönmez C (2012) In: Begum G (ed) Comparative genotoxicity analysis of heavy metal contamination in higher plants. Chapter 6 in ecotoxicology. IntechOpen, London, pp 107-124. https://doi.org/10.5772/30073

Awange J, Obera B (2007) Motor vehicles: are they emerging threats to Lake Victoria and its environment? Water Air Soil Pollut 182:4356. https://doi.org/10.1007/s11270-006-9319-3

Baker A (1981) Accumulators and excluders strategies in response of plants to heavy metals. J Plant Nutr 3:643-654. https://doi.org/10. 1080/01904168109362867

Brankovic S, Glišić R, Topuzovic M, Marin M (2015) Uptake of seven metals by two macrophytes species: potential for phytoaccumulation and phytoremediation. Chem Ecol 31:583-593. https://doi.org/10. 1080/02757540.2015.1077812

Burton GA (2002) Sediment quality criteria in use around the world. Limnology 3:65-76. https://doi.org/10.1007/s102010200008

Crul RCM (1995) Limnology and hydrology of Lake Victoria: comprehensive and comparative study of Great Lakes. In: Studies and Reports in Hydrology, vol 53. UNESCO, Paris

Davidson CM (2013) Methods for the determination of heavy metals and metalloids in soils. In: Alloway BJ (ed) Heavy metals in soils. Springer, Berlin

de Deckere E, De Cooman W, Leloup V, Meire P, Schmitt C, von der Ohe PC (2011) Development of sediment quality guidelines for freshwater ecosystems. J Soils Sediments 11:504-517. https://doi.org/10. 1007/s11368-010-0328-x

Dhankher OP (2005) Arsenic metabolism in plants: an inside story. New Phytol 168:503-505. https://doi.org/10.1111/j.1469-8137.2005. 01598.x

Dudgeon D, Arthington AH, Gessner MO, Kawabata ZI, Knowler DJ, Lévêque C, Naiman RJ, Prieur-Richard AH, Soto D, Stiassny MLJ, Sullivan CA (2006) Freshwater biodiversity: importance, threats, status and conservation challenges. Biol Rev 81:163-182. https:// doi.org/10.1017/S1464793105006950

EU (2001) Parameters of water quality: interpretation and standards. Ireland

Favas PJ, Pratas J, Prasad MN (2012) Accumulation of arsenic by aquatic plants in large-scale field conditions: opportunities for phytoremediation and bioindication. Sci Total Environ 433:390 397. https://doi.org/10.1016/j.scitotenv.2012.06.091

Galal TM, Shehata SH (2015) Bioaccumulation and translocation of heavy metals by Plantago major L. grown in contaminated soils under the effect of traffic pollution. Ecol Indic 48:244-251. https:// doi.org/10.1016/j.ecolind.2014.08.013

Galal TM, Gharib FA, Ghazi SM, Mansour KH (2017) Phytostabilization of heavy metals by the emergent macrophyte Vossia cuspidata (Roxb.) Griff.: a phytoremediation approach. Int J Phytoremediation 19:992-999. https://doi.org/10.1080/15226514. 2017.1303816

Games PA, Howell JF (1976) Pairwise multiple comparison procedures with unequal N's and/or variances: a Monte Carlo study. J Educ Stat 1:113-125. https://doi.org/10.2307/1164979

Hou D, He J, Lü C, Ren L, Fan Q, Wang J, Xie Z (2013) Distribution characteristics and potential ecological risk assessment of heavy metals $(\mathrm{Cu}, \mathrm{Pb}, \mathrm{Zn}, \mathrm{Cd})$ in water and sediments from Lake Dalinouer, China. Ecotoxicol Environ Saf 93:135-144. https://doi. org/10.1016/j.ecoenv.2013.03.012

Kastratovic V, Krivokapic S, Bigović M, Djurovic D, Blagojevic N (2014) Bioaccumulation and translocation of heavy metals by Ceratophyllum demersum from Skadar Lake, Montenegro. J Serb Chem Soc 79:74. https://doi.org/10.2298/JSC140409074K

Kessler R (2014) Lead-based decorative paints: where are they still soldand why? Environ Health Perspect 122:A96-A103. https://doi.org/ 10.1289/ehp.122-A96 
Kim H-Y (2015) Statistical notes for clinical researchers: post-hoc multiple comparisons. Restorative Dentistry \& Endodontics 40:172176. https://doi.org/10.5395/rde.2015.40.2.172

Kishe-Machumu M, Machiwa J (2003) Distribution of heavy metals in sediments of Mwanza Gulf of Lake Victoria, Tanzania. Environ Int 28:619-625. https://doi.org/10.1016/S0160-4120(02)00099-5

Knocke WR, Conley L, Van Benschoten JE (1992) Impact of dissolved organic carbon on the removal of iron during water treatment. Water Res 26:1515-1522. https://doi.org/10.1016/0043-1354(92)90072-C

Kobingi N, Raburu PO, Masese FO, Gichuki J (2009) Assessment of pollution impacts on the ecological integrity of the Kisian and Kisat rivers in Lake Victoria drainage basin, Kenya. Afr J Environ Sci Technol 3:097-107

Kundu R, Aura CM, Nyamweya C, Agembe S, Sitoki L, Lung'ayia HBO, Ongore C, Ogari Z, Werimo K (2017) Changes in pollution indicators in Lake Victoria, Kenya and their implications for lake and catchment management. Lakes Reserv Res Manag 22:199-214. https://doi.org/10.1111//re.12187

Lau S, Mohamed M, Tan Chi Yen A, Su'ut S (1998) Accumulation of heavy metals in freshwater molluscs. Sci Total Environ 214:113121. https://doi.org/10.1016/S0048-9697(98)00058-8

Li J, Yu H, Luan Y (2015) Meta-analysis of the copper, zinc, and cadmium absorption capacities of aquatic plants in heavy metal-polluted water. Int J Environ Res Public Health 12:14958-14973. https://doi. org/10.3390/ijerph121214959

Loiselle SA, Azza N, Gichuki J, Bracchini L, Tognazzi A, Dattilo AM, Rossi C, Cozar A (2010) Spatial dynamics of chromophoric dissolved organic matter in nearshore waters of Lake Victoria. Aquat Ecosyst Health Manag 13:185-195. https://doi.org/10.1080/ 14634988.2010.481236

Lowry GV, Espinasse BP, Badireddy AR, Richardson CJ, Reinsch BC, Bryant LD, Bone AJ, Deonarine A, Chae S, Therezien M, Colman BP, Hsu-Kim H, Bernhardt ES, Matson CW, Wiesner MR (2012) Long-term transformation and fate of manufactured $\mathrm{Ag}$ nanoparticles in a simulated large scale freshwater emergent wetland. Environ Sci Technol 46:7027-7036. https://doi.org/10.1021/es204608d

Lung'ayia H, Sitoki L, Kenyanya M (2001) The nutrient enrichment of Lake Victoria (Kenyan Waters). Hydrobiologia 458:75-82. https:// doi.org/10.1023/A:1013128027773

MacDonald D, Ingersoll CG, Berger TA (2000) Development and evaluation of consensus-based sediment quality guidelines for freshwater systems. Arch Environ Contam Toxicol 39:20-31. https://doi. org/10.1007/s002440010075

Mahommed NK, Makundi I (2002) Optimization of EDXRF for the study of heavy metal pollution of Lake Victoria. Tanzan J Sci 28(1):7-24. https://doi.org/10.4314/tjs.v28i1.18315

Makokha A, Mghweno L, Magoha H, Nakajugo A, M Wekesa J (2008) Environmental lead pollution and contamination in food around Lake Victoria, Kisumu, Kenya. Afr J Environ Sci Technol 2:349-353

McCartor A, Becker D (2010) Blacksmith Institute's World's Worst Pollution Problems Report 2010. https://doi.org/10.13140/RG.2.1. 3761.5203

McGillicuddy E, Murray I, Kavanagh S, Morrison L, Fogarty A, Cormican M, Dockery P, Prendergast M, Rowan N, Morris D (2017) Silver nanoparticles in the environment: sources, detection and ecotoxicology. Sci Total Environ 575:231-246. https://doi.org/ 10.1016/j.scitotenv.2016.10.041

Miller J, Hudson-Edwards K, J Lechler P, Preston D, Macklin M (2004) Heavy metal contamination of water, soil and produce within riverine communities of the Rio Pilcomayo Basin, Bolivia. Sci Total Environ 320:189-209. https://doi.org/10.1016/j.scitotenv.2003.08.011

Mohd RN, Yap B (2011) Power comparisons of Shapiro-Wilk, Kolmogorov-Smirnov, Lilliefors and Anderson-Darling tests. J Stat Model Analytics 2:21-33 http://www.de.ufpb.br/ ulisses/ disciplinas/normality_tests_comparison.pdf
Muli J (2006) Environmental problems of Lake Victoria (East Africa): what the international community can do. Lakes Reserv Res Manag 2:47-53. https://doi.org/10.1111/j.1440-1770.1996.tb00047.x

Mwamburi J, Oloo NF (1996) The distribution and concentration levels of trace metals in water and sediments of Lake Victoria, Kenya. Afr J Trop Hydrobiol Fish 7:37-48. https://doi.org/10.4314/ajthf.v7i1. 1381

Nabulo G, Oryem-Origa H, Nasinyama G, Cole D (2008) Assessment of $\mathrm{Zn}, \mathrm{Cu}, \mathrm{Pb}$ and $\mathrm{Ni}$ contamination in wetland soils and plants in the Lake Victoria basin. Int J Environ Sci Technol 5(1):65-74

Njiru M, Kazungu J, Ngugi C, Gichuki J, Muhoozi L (2008) An overview of the current status of Lake Victoria fishery: opportunities, challenges and management strategies. Lakes Reserv Res Manag 13:112. https://doi.org/10.1111/j.1440-1770.2007.00358.x

Njuru P, Hecky RE (2005) Nutrient concentrations in Nyanza Gulf, Lake Victoria, Kenya: light limits algal demand and abundance. Hydrobiologia 534:131-140. https://doi.org/10.1007/s10750-0041418-9

Njuru P, Hecky RE, Guildford SJ, Macintyre S (2013) Spatial variability of nutrient concentrations, fluxes, and ecosystem metabolism in Nyanza Gulf and Rusinga Channel, Lake Victoria (East Africa). Limnol Oceanogr 58:774-789. https://doi.org/10.4319/lo.2013.58. 3.0774

Nyilitya B, Mureithi SM, Boeckx P (2016) Tracking sources of excess nitrate discharge in Lake Victoria, Kenya for improved nitrogen use efficiency in the catchment. Paper presented at the International Nitrogen Initiative Conference, "Solutions to improve nitrogen use efficiency for the world", Melbourne, Australia

Ochieng E, Lalah J, Wandiga S (2006) Heavy metals in water and surface sediments in Winam Gulf of Lake Victoria, Kenya. Bull Environ Contam Toxicol 77:459-468. https://doi.org/10.1007/s00128-006$1087-7$

OECD (2007) Proposed system of surface water quality standards for Moldova: Technical Report Moldova

Okely P, Imberger J, Antenucci J (2010) Processes affecting horizontal mixing and dispersion in Winam Gulf, Lake Victoria. Limnol Oceanogr 55:1865-1880. https://doi.org/10.4319/lo.2010.55.5. 1865

Okungu JO, Njoka S, Abuodha JOZ, Hecky RE (2005) An introduction to Lake Victoria catchment, water quality, physical limnology and ecosystem status (Kenyan sector). In: Abuodha JOZ, Hecky RE (eds) Lake Victoria environment report water quality and ecosystem status: Kenya National Water Quality Synthesis Report. Lake Victoria Environment Management Project (LVEMP), Kisumu, pp $1-27$

Onyari J, Wandiga S (1989) Distribution of Cr, Pb, Cd, Zn, Fe and Mn in Lake Victoria sediments, East Africa. Bull Environ Contam Toxicol 42:807-813. https://doi.org/10.1007/BF01701619

Otachi E, Körner W, Avenant-Oldewage A, Fellner-Frank C, Jirsa F (2014) Trace elements in sediments, blue spotted tilapia Oreochromis leucostictus (Trewavas, 1933) and its parasite Contracaecum multipapillatum from Lake Naivasha, Kenya, including a comprehensive health risk analysis. Environ Sci Pollut Res Int 21:7339-7349. https://doi.org/10.1007/s11356-014-2602-8

Plessl C, Gilbert B, Sigmund MF, Theiner S, Avenant-Oldewage A, Keppler B, Jirsa F (2018) Mercury, silver, selenium and other trace elements in three cyprinid fish species from the Vaal Dam, South Africa, including implications for fish consumers. Sci Total Environ 659. https://doi.org/10.1016/j.scitotenv.2018.12.442

Ramlal PS, Bugenyi FWB, Kling GW, Nriagu JO, Rudd JWM, Campbell LM (2003) Mercury concentrations in water, sediment, and biota from Lake Victoria, East Africa. J Great Lakes Res 29:283-291. https://doi.org/10.1016/S0380-1330(03)70555-3

Remon E, Bouchardon J, Le Guédard M, Bessoule J-J, Conord C, Faure O (2013) Are plants useful as accumulation indicators of metal 
bioavaibility? Environ Pollut 175C:1-7. https://doi.org/10.1016/j. envpol.2012.12.015

Roberts TL (2014) Cadmium and phosphorous fertilizers: the issues and the science. Procedia Eng 83:52-59. https://doi.org/10.1016/j. proeng.2014.09.012

Sayer CA, Máiz-Tomé L, Darwall WRT (2018) The importance of freshwater species to livelihoods in the Lake Victoria Basin. In: Freshwater biodiversity in the Lake Victoria Basin: guidance for species conservation, site protection, climate resilience and sustainable livelihoods. IUCN UK, IUCN Gland, Switzerland, Gland, pp 136-151

Simpson S, Batley G, Chariton A (2013) Revision of the ANZECC/ ARMCANZ sediment quality guidelines. In: CSIRO Land and Water Science Report 08/07. CSIRO Land and Water, Clayton

Skwierawski A, Sidoruk M (2014) Heavy metal concentrations in the sediment profiles of the anthropogenically transformed Plociduga reservoir. Ecol Chem Eng 21:79-88. https://doi.org/10.2478/eces2014-0007

Sobek S, Tranvik L, Prairie Y, Kortelainen P, Cole J (2007) Patterns and regulation of dissolved organic carbon: an analysis of 7,500 widely distributed lakes. Limnol Oceanogr 52:1208-1219. https://doi.org/ 10.4319/lo.2007.52.3.1208

Stanković Ž, Pajević S, Vučković M, Stojanović S (2000) Concentrations of trace metals in dominant aquatic plants of the Lake Provala (Vojvodina, Yugoslavia). Biol Plant 43:583-585. https://doi.org/ 10.1023/A:1002806822988

Turekian KT, Wedepohl KH (1961) Distribution of the elements in some major units of the Earth's crust. Geol Soc Am Bull 72:175. https:// doi.org/10.1130/0016-7606(1961)72[175:DOTEIS]2.0.CO;2

Verhoeven JTA, Arheimer B, Yin C, Hefting MM (2006) Regional and global concerns over wetlands and water quality. Trends Ecol Evol 21:96-103. https://doi.org/10.1016/j.tree.2005.11.015

Wetzel RG, Likens GE (1991) Limnological analyses. Springer-Verlag New York. https://doi.org/10.1007/978-1-4757-4098-1
WHO (2002) Silver and silver compounds: environmental aspects. World Health Organisation, Geneva

Winch S, Ridal J, Lean D (2002) Increased metal bioavailability following alteration of freshwater dissolved organic carbon by ultraviolet $\mathrm{B}$ radiation exposure. Environ Toxicol 17:267-274. https://doi.org/10. 1002/tox.10057

Xing W, Huang W, Liu G (2010) Effect of excess iron and copper on physiology of aquatic plant Spirodela polyrrhiza (L.) Schleid. Environ Toxicol 25:103-112. https://doi.org/10.1002/tox.20480

Xing W, Wu H, Hao B, Liu G (2013) Metal accumulation by submerged macrophytes in eutrophic lakes at the watershed scale. Environ Sci Pollut Res 20(10):6999-7008. https://doi.org/10.1007/s11356-0131854-z

Yang X, Xiong B, Yang M (2010) Relationships among heavy metals and organic matter in sediment cores from Lake Nanhu, an Urban Lake in Wuhan, China. J Freshw Ecol 25:243-249. https://doi.org/10. 1080/02705060.2010.9665074

Yang W, Seager R, Cane M, Lyon B (2015) The annual cycle of East African precipitation. J Clim 28:2385-2404. https://doi.org/10. 1175/JCLI-D-14-00484.1

Yuan L, Richardson CJ, Ho M, Willis CW, Colman BP, Wiesner MR (2018) Stress responses of aquatic plants to silver nanoparticles. Environ Sci Technol 52:2558-2565. https://doi.org/10.1021/acs. est. $7 \mathrm{~b} 05837$

Zhang C, Yu ZG, Zeng GM, Jiang M, Yang ZZ, Cui F, Zhu MY, Shen LQ, Hu L (2014) Effects of sediment geochemical properties on heavy metal bioavailability. Environ Int 73C:270-281. https://doi. org/10.1016/j.envint.2014.08.010

Publisher's note Springer Nature remains neutral with regard to jurisdictional claims in published maps and institutional affiliations. 